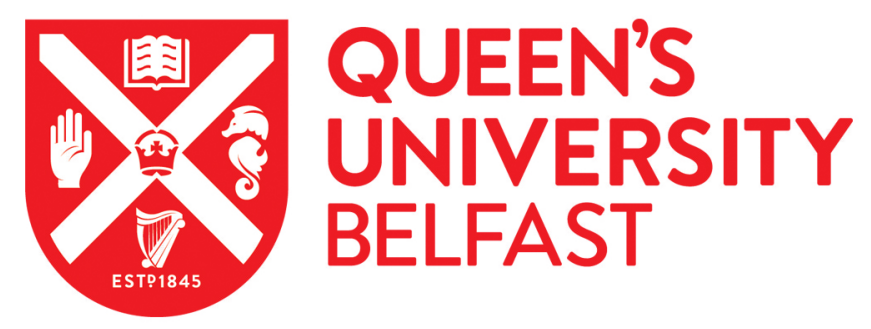

\title{
Creating opportunities in the face of an environmental jolt: Exploring turnaround strategizing practices within large Irish construction contractors
}

Tansey, P., Spillane, J., \& Brooks, T. (2017). Creating opportunities in the face of an environmental jolt:

Exploring turnaround strategizing practices within large lrish construction contractors. Construction Management Economics, 36(4), 217-241. https://doi.org/10.1080/01446193.2017.1368679

\section{Published in:}

Construction Management Economics

\section{Document Version:}

Peer reviewed version

Queen's University Belfast - Research Portal:

Link to publication record in Queen's University Belfast Research Portal

\author{
Publisher rights \\ (c) 2017 Informa UK Limited, trading as Taylor \& Francis Group. This work is made available online in accordance with the publisher's \\ policies. Please refer to any applicable terms of use of the publisher.
}

\section{General rights}

Copyright for the publications made accessible via the Queen's University Belfast Research Portal is retained by the author(s) and / or other copyright owners and it is a condition of accessing these publications that users recognise and abide by the legal requirements associated with these rights.

\section{Take down policy}

The Research Portal is Queen's institutional repository that provides access to Queen's research output. Every effort has been made to ensure that content in the Research Portal does not infringe any person's rights, or applicable UK laws. If you discover content in the

Research Portal that you believe breaches copyright or violates any law, please contact openaccess@qub.ac.uk. 


\title{
CREATING OPPORTUNITIES IN THE FACE OF AN ENVIRONMENTAL JOLT: EXPLORING TURNAROUND STRATEGISING PRACTICES WITHIN LARGE IRISH CONSTRUCTION CONTRACTORS
}

\author{
PAUL TANSEY, JOHN P. SPILLANE, and TARA BROOKS
}

Firms that face organisational decline choreographed from an environmental jolt must seek new ways of creating opportunities in order to successfully turnaround. As such, the identification of pertinent turnaround strategies becomes increasingly important for senior management. Within the strategy-as-practice scholarly, there have been recent calls to move beyond empirical 'isolationism' and to connect with other larger social phenomena; while across the turnaround literature there have been calls to explore the process and microstructure of turnaround strategies in cyclical environments. To address this research gap, the purpose of the study is to adopt a tall ontology by blending the strategy-as-practice lens with the organisational decline and turnaround lens. By drawing on five exploratory case studies of large Irish construction contractors, the central objective is thus to explore firms' turnaround strategising practices during an environmental jolt. In order to advance our tall ontology, we developed a turnaround strategising process model (and propositions) that integrates our findings, and which offers the fundamental building blocks of a new blended theory. We find that successful turnaround attempts entail the simultaneous interaction of non-aggressive cost retrenchment actions and non-extensive internationalisation. The case studies further suggest that during a prolonged environmental jolt, cost retrenchment is more often a long-term strategy. Lastly, the findings provide valuable support for practitioners in developing a successful turnaround response, and in aiding the selection and timing of operational and strategic actions.

Keywords: Internationalisation, Ireland, organisational turnaround, retrenchment, strategy as practice 


\section{INTRODUCTION}

The 2007 economic recession caused catastrophic upheavals across numerous industry environments, reflecting the most severe economic recession since the Great Depression of the 1930s. The challenging economic environment that unfolded sent unconceivable shockwaves across the construction sector (Tansey and Spillane 2014, Brooks et al. 2016), surpassing the command of experienced managers and overwhelming ever resilient firms. In this sense, the recent economic recession exemplifies an environmental jolt, which is a sudden and unprecedented event that surprises firms and often drastically changes outcomes of strategic actions (Meyer 1982). Moreover, in an environmental jolt, the level of environmental munificence (level of resources available in a particular environment) tends to fluctuate significantly (Dess and Beard 1984). The 2007 economic recession, best exemplified by an interest rate increase in the United States in July 2007 (Knopp 2010), created a long-term pattern of contraction across the Irish construction industry; with declines in employment of $65 \%$ reported over a six year period (CIF 2015). According to Arogyaswamy and colleagues (1995), such an industry contraction-based decline tends to reduce the number of firms in an industry as they compete relentlessly for a reduced resource base. This sudden change in munificence level in the construction industry provides a natural experiment to investigate turnaround strategising practices of Irish construction firms.

While turnaround and organisational decline scholars have predominately investigated turnaround situations caused from internal decline (e.g. Barker and Mone 1994, Barker and Duhaime 1997, Nixon et al. 2004), less is understood about turnaround situations during an environmental jolt, especially in the construction management domain. A reason for the lack of empirical work, maybe that industries in flux 
normally make unattractive research settings (Meyer et al. 1990). Nevertheless, Ndofor and colleagues (2013, p. 1132) recently called for scholars to "examine potential turnaround actions in a greater number of industry environments'...'in industries going through cyclical contractions due to a recession'. Turnaround scholars have also identified a failure in capturing the dynamics of decline and recovery in specific industries, and more specifically, a lack of exploration into the microprocesses of turnaround strategies (Sudarsanam and Lai 2001). Analogous with this, strategy-as-practice scholars have acknowledged that problems posed in mainstream strategy research might be aided by a practice-based approach (Jarzabkowski 2005, Ambrosini et al. 2007). Others have called on researchers to avoid empirical 'microisolationism' through linking with 'larger' social phenomena (e.g. Seidl and Whittington 2014). Indeed, by blending macro and micro theoretical perspectives, Jarzabkowski et al. (2007) contends that this would seek to advance explanations of strategy making by using different levels and units of analysis. In order to address this research gap, the purpose of the study is to adopt a tall ontology by blending the strategy-as-practice micro perspective with the macro traditions of organisational decline and turnaround. By drawing on five exploratory case studies of large Irish construction contractors, the central objective is therefore to explore firms' turnaround strategising practices during the period 2007 - 2015; a period of economic contraction and growth. Analogous with this, the sub-objectives of the study are: (1) to understand when, how, and why certain turnaround strategising practices occurred during the period; (2) to explore episodes of strategy-making within the practices of internationalisation and cost retrenchment; and (3) to develop a turnaround strategising process model and associated propositions for future testing. 
As an empirical study of turnaround strategising practices, our study makes three important contributions to knowledge. First, by successfully integrating macro and micro perspectives - organisational decline and turnaround, and strategy-as-practice lens - we develop the fundamental building blocks of a turnaround strategising process model which represents a new perspective that differs from past models. We introduce the concept of 'time' into a blended turnaround and strategy-as-practice perspective, and also offer an extended process model which captures the complexity of 'time' in terms of multiple practices, concurrencies and patterns. Second, by exploring the micro-processes of turnaround strategies we contribute to the turnaround literature by building on the work of Trahms et al. (2013). In so doing, we introduce the concepts of both internal, and external response factors - in the form of socially embedded and newly integrated response factors. We further conceptualise firm actions by introducing the concept of practice intensity, along with existing theoretical strategyas-practice constructs, such as, strategy-making episode, micro-level strategising praxis, and practice outcomes. Third, by offering unique insights into episodes of strategy-making during an environmental jolt, we contribute to the strategy as practice literature. We distinctively build on the work of Regner (2003) by illustrating strategy-making episodes within the practices of internationalisation and cost retrenchment, and also by introducing a new 'abductive' approach.

In the following section, we begin by firstly reviewing the extant organisational decline and turnaround literature, followed by the strategy-as-practice literature. We then serve to move beyond micro-isolationism by uniting both theoretical perspectives. Moving on, we describe our research method, in the form of; research design, selection procedure and cases, the empirical inquiry, followed by the data analysis. We then present our findings using three main branches - response factors, 
firm actions, and outcomes. Under each branch, the first order findings provide a narrative of the turnaround strategies during the period 2007-2015. Using the strategy as practice lens, we then establish second order explanations of our findings, which help us explain in more detail how and why turnaround strategising practices occurred. After detailing the findings, we offer a discussion on the respective results. Lastly, the conclusions are depicted, along with recommendations and avenues for future research. 


\section{THEORETICAL BACKGROUND}

\section{Organisational Decline and the Turnaround Process}

Ruminating from the seminal works of Schendel, Patton, and Riggs (1976), Hofer (1980), and Bibeault (1982), is two diverging categories of theories. On the one hand, organisational retrenchment is seen as an integral component of the turnaround process (see, for example, Pearce and Robbins 1993, Trahms et al. 2013), while the second research stream identifies organisational retrenchment as a stand-alone tactical response to a decline in financial performance (see, for example, Freeman and Cameron 1993, DeDee and Vorbies 1998). Given that the general economy is now in recovery mode following the aftermath of the 2007 economic recession, the intent of this research is to adopt the former research stream, namely, the turnaround process.

Regarding the constructs of 'organisational decline' and 'turnaround' we draw from the literature on organisational turnaround (e.g. Pearce and Robbins 1993, Barker and Mone 1994, Trahms et al. 2013). We follow the early lead of Schendel and colleagues (1976, p. 3), in defining turnaround as 'a decline and recovery in performance'. In order to insure a need for strategic change, we follow McKinley, Latham and Braun's (2014, p. 90) definition of organisational decline as 'a successive year-after-year decrease in an organisation's resource base than lasts for at least two years'. Indeed, we draw on these definitions from the turnaround literature because the respective definitions used in that literature is quite specific. Additionally, we emphasize that there is no inference that all firms experiencing decline will turn around.

Following Bibeault's (1982) multistage perspective of the turnaround process, Robbins and Pearce (1992) empirically tested a two-stage model of turnaround by drawing on 32 publicly held American textile manufacturing firms during the 
economic turbulence of the 1980s. They found that retrenchment was a critical first stage strategic element in attaining successful turnaround. Building on their original empirical work, Pearce and Robbins (1993) developed a two-stage turnaround response model which pointed to the significance of severity and causality in determining the turnaround response. According to the logical flow of the model, turnaround is a two-stage process whereby retrenchment is followed by strategic actions. It was this rigid, sequential flow, and narrow scope, that was criticised by authors such as Barker and Mone (1994) and Arogyaswamy et al. (1995). In particular, Arogyaswamy et al. (1995) argued that turnaround is not time-sequential and thus should entail interactions (feedback loops) between stages. Building on the influential works of Pearse and Robbins (1993), Trahms et al. (2013) conducted a comprehensive review of decline and turnaround literature that occurred since 1993. They proposed a more compendious model (see Figure 1) by incorporating new additions to the turnaround process, whilst also appeasing key criticisms highlighted in previous turnaround debates. To this end, use of the model is warranted as it contains important components that will help explain how firms strategise during turnaround situations.

\section{Model of Organisational Decline and Turnaround}

Causes of Decline. This entails external and internal factors, which lead to a firm's response to decline. External causes of organisational decline include changes such as environmental jolts (cf. Meyer 1982), technological changes, industry decline, and competitive dynamics. Examples of an 'environmental jolt' include; natural disasters, unexpected tax hikes, and sudden economic downturns (Venkataraman and Van de Ven 1998). 
Response Factors. These factors form the interface between the causes of organisational decline and the actions that the firm takes to reverse the decline. The managerial cognitive concept (borrowed from the psychology field) entails factors such as; awareness of decline, attribution of decline, and perception of the decline's severity, which subsequently affect the turnaround actions employed. Another trigger, severity of the turnaround situation, indicates how close the firm is to financial insolvency or break-even (Hofer 1980, Hambrick and Schecter 1983), with low severity usually entailing cost retrenchment, and high severity generally encompassing asset retrenchment (Pearce and Robbins 1993). Regarding the influence of stakeholders in a turnaround situation, Trahms et al. (2013) stressed that empirical investigation was lacking. An exception to this was the empirical research of Pajunen (2006). He investigated stakeholder influences on the organisational survival of a Finnish pulp and paper industry firm, and found that continual communication and fair relationships with key stakeholders enhances organisational survival. He also identified two critical elements of stakeholder influence in organisational survival, i.e. resource-dependence and network-position based powers.

Firm Actions - strategic. Firms often pursue strategic and operational actions in response to organisational decline. Strategic actions are thought to be a true driver of long-term performance gains following decline (Trahms et al. 2013); incorporating changes or adjustments in a firm's domain (Barker and Duhaime 1997, Ndofor et al. 2013). For instance, reconfiguring existing resources and capabilities into new product offerings, or acquiring new resources and capabilities externally through strategic alliances were found to aid organisational recovery (Morrow et al. 2007). Diversification into new markets, both domestically and internationally, have found to be an important strategic response to poor financial performance (Ramanujam and 
Varadarajan 1989). Indeed, Barker and Duhaime (1997) found that extensive strategic reorientation during an industry contraction-based decline can be quite percarious, pushing a declining firm even further towards failure. This type of offensive move has been empirically linked to firms with organisational slack (Jenson and Meckling 1976, Tan and See 2004). Regarding domestic vs foreign expansion, Chen and Martin (2001, p.562), argued that 'domestic expansion will delay or reduce a firm's foreign expansion'.

Even though diversification has long been a central topic of strategic management research, other rival theories from the international business realm, such as Dunnings (2003) OLI (Ownership-Location-Internalization) paradigm, potentially offer some useful insights and explanations regarding internationlisation. For instance, the framework can be used to demonstrate specific ownership, locational, and internalisation advantages that some firms have when competing against others in the international market. Indeed, a number of authors across numerous industries have successfully utilised the OLI paradigm in examining international business (e.g. Doh 2005, Pheng and Hongbin 2006, Dunning and Lundan 2008). Although there are certain similarities between the eclectic paradigm and turnaround research (e.g. ownership advantages through resource availability - organisational slack), it does offer some alternative perpsectives. For example, in regard to choice of location, macro level locational factors such as government policies, regulatory barriers of entry, competitive intensity, as well as availability of local resources, can affect a firms strategic direction even during a turnaround situation. Interestingly, in a study of Chinese construction multinational corporations (MNCs), Pheng and Hongbin (2006) found the availability and costs of local workers, and the political and social stability in the host countries, to be some of the most important locational factors. 
Firm Actions - operational. Used as a synonym to retrenchment actions, operational actions focus on achieving short-run cost and asset reductions (Michael and Robbins 1998). Often referred to as 'stopping the bleeding' (Bibeault 1982), these actions involve deliberate reductions in costs, assets and overheads of the firm as it starts its turnaround effort (Pearse and Robbins 1993). Robbins and Pearce (1992) argued that along with cost retrenchment, asset retrenchment could also be required by firms who encounter more severe turnaround situations. Empirical research on the effect of retrenchment in the turnaround process has been both conflicting and inconsistent. On the one hand, retrenchment is deemed an integral component in achieving recovery from decline (Robbins and Pearce 1992), while in contrast, turnaround success is attributable to revenue gains rather than cost and asset reductions (Barker and Mone 1994). To counteract organisational decline and thus reduce firm labour costs, cost reducing actions can often involve employee layoffs (i.e. downsizing) and reductions in salaries (Barker et al. 1998, Tansey et al. 2014). Although labour costs are reduced, some authors have argued that excessive retrenchment actions could hinder turnaround attempts and subsequently have a negative effect on performance (see for example, Nixon et al. 2004). Aside from performance declines, there is growing literature on the hidden costs of organisational downsizing (Ndofor et al. 2013). For instance, Datta et al. (2010) argued that employee downsizing has the potential to disrupt relationships and social networks, and to increase employee overload and burnout.

Outcomes. As Trahms and colleagues (2013) outlined in their review, there are some underlying issues regarding the measure of performance turnaround. There is general agreement that to constitute a successful recovery, performance measures should be at least positive (Barker and Duhaime 1997). However, there is a lack of agreement 
regarding the duration that the reversal of the decline has to last; with some arguing that one year is sufficient to confirm a successful turnaround (e.g. Morrow et al. 2007), while others argue that at least three years of sustained positive performance is required (e.g. Barker and Duhaime 1997, Furrer et al. 2007). In this sense, we take a more conservative approach and classify turnaround success as a return to the same pre-downturn levels of performance (Pearce and Robbins 1993, Sudarsanam and Lai 2001). To account for firms that do not fully attain 'turnaround success', we adopt Moulton and Thomas (1993) concept of 'partial turnaround success'. In sum, to broaden our research on 'firm actions' and to move beyond generic strategies reported in the extant literature, we draw on the strategy-as-practice (Whittington 2006, Jarzabkowski et al. 2007) approach to strategy process in order to investigate the micro-level context of turnaround strategising practices.

\section{The 'strategy-as-practice' perspective}

Compared to turnaround research, strategy-as-practice (hereafter 'SAP') has more recent origins, emerging in particular from the theoretical work of Whittington (1996), and the empirical work of Jarzabkowski and Wilson (2002), and Johnson et al. (2003). However, the SAP approach has its theoretical roots born out of 'theories of practice' (Vaara \& Whittington 2012), which can be traced back to the works of Wittgenstein (1951) and Heidegger (1962). By tradition, strategy theorists have viewed strategies as something that firms have (Whittington 2006), however, recent contemporary movements emphasise SAP as something that people do (e.g. Jarzabkowski 2004). This re-configuration towards SAP, allows scholars to achieve a deeper understanding of strategising in firms, as it focuses on the practices that are instigated and reinstigated in the 'doing' of strategy (Rasche and Chia 2009). Emerging from more contemporary scholarship, the SAP perspective offers an alternative approach that is 
evidently distinct from the traditional process view (Chia and MacKay 2007). Albeit, strategy process studies focus on strategic decision-making as whole processes (Whittington 1996) and on change events from a firm-level of analysis (Paroutis and Pettigrew 2007); SAP research focus more on micro-activities (Whittington 1996), micro-processes (Brown and Duguid 2000), and on the respective routines and procedures entailed in endorsing strategy (Jarzabkowski and Wilson 2002).

\section{Strategising Conceptual Framework}

Now central to the practice tradition, the widely used strategising conceptual framework (see Figure 2) developed by Whittington (2006) and furthermore by Jarzabkowski et al. (2007), provide a canonical axiom for analysing SAP. The framework consists of three core and interrelated themes: practices, praxis, and practitioners; with strategising at its nexus. Segments A, B, and C represent interconnections, whereby it is not possible to examine one theme without drawing on the others. Following the lead of German sociologist Andreas Reckwitz (2002), Whittington (2006, p. 619) depicts practices as 'shared routines of behaviour, including traditions, norms, and procedures for thinking, acting and using things'; praxis as 'actual activity, what people do in practice'; and practitioners as 'strategy actors, the strategists who both perform this activity and carry out its practices'. Notwithstanding the importance of all three themes, the scope of this study centres mainly on micro-level strategising praxis.

Praxis. SAP research has also magnetised around praxis, typically focusing on episodes of strategy-making (Vaara and Whittington 2012), and investigating the activity 'inside' the process (Brown and Duguid 2001). Within a diverse set of approaches to theorising about praxis (e.g. capabilities, framing, etc.), our focus is 
predominately on aspects of resources and emergence; which potentially provide micro-level minutiae.

Regarding the resource-based view, Salvato (2003) used a comparative case study approach to identify 'core micro-strategies' (set of resources and organisational routines). These resulted from accumulated experience, and can be leveraged and recombined by management to achieve dynamism. In a similar vein, other SAP research sheds light on specific constructs of the Bower - Burgelman (hereafter 'BB') process model of strategy-making. Central to the core of the B-B model is its conceptualisation of strategy making as an 'iterated process of resource allocation' (Noda and Bower 1996, p. 159). For example, Mirabeau and Maguire (2014) draw on an exploratory longitudinal case study of a global telecommunications firm in order to examine how emergent strategies form. They found that influences from external stakeholders can be harnessed by managers to mobilise resources internally. Emergent strategies in SAP research have received little attention (Tsoukas 2010), with Vaara and Whittington (2012, p. 310) calling for further progress with regard to 'exploring emergence in strategy-making'. In an early study, Regnér (2003) used a dual longitudinal case methodology to examine how managers create and develop strategy in practice. They identified a strategy making dichotomy of inductive and deductive episodes across the periphery and centre locations respectively. Inductive strategy making was developed through explorative activities (e.g. trial and error, informal contacts) and contributed to the creation of new strategies, while deductive strategy making entailed an industry and exploitation focus that aligned with the existing strategy. He also confronted the notion of sensemaking (cf. Weick 1995), exploring how managers make sense of strategy. Following the initiation of strategic change, sensemaking processes attempt to counteract the associated uncertainty and 
enigma (Balogun and Johnson 2005). Indeed, Gioia and Chittipeddi (1991), found that top management initially try to 'figure out' strategy-relevant threats and opportunities before construing a vision. Analogous with this, SAP research also sheds light on the 'strategy as practical coping' and 'strategy without design' perspectives, put forward by Chia and Holt (2006, 2009). Drawing from the work of philosopher Martin Heidegger, Chia and Holt (2006) argue that successful strategies can emerge unintentionally through everyday 'practical coping' actions, even without the existence of purposeful strategic plans.

\section{Beyond isolationism: blending turnaround and strategy-as-practice perspectives}

The possibility of uniting macro factors with micro factors has been recently debated across the organisational, management, and strategy scholarship (Barney and Felin 2013). Many decades ago social scientists were torn between methodological individualism or methodological collectivism. For instance, Durkheim (1962) argued that the social sciences should focus on higher social and macro factors, while Simmel (1974) contended that the individual was the basic building block of social theories. More recently, Barney and Felin (2013, p139) argued that 'to understand any collective phenomenon or thing, we need to understand the constituent parts that make it up: individuals and their social interaction'. Indeed, numerous scholars have successfully united diverse theoretical traditions within the strategic management domain. For instance, Mirabeau and Maguire (2014) developed a process model of emergent strategy formation, by combining Mintzberg's (1978) model of strategy formation with both the B-B model and the SAP approach. Furthermore, Regnér (2008, 2016) conceptually demonstrated the compatibility of the SAP approach with 
the resource based view, dynamic capabilities view, and the micro-foundations perspective.

In the turnaround literature, for example, Sudarsanam and Lai (2001) stressed that there was a need to identify turnaround strategies beyond the generic ones of restructuring and retrenchment, and also to explore the process and microstructure of such actions. They further argued that this shortfall may explain why there are large similarities between recovery and non-recovery firms reported in the extant turnaround literature. Whilst turnaround research has been previously linked to mechanistic views of strategy (e.g. Lim et al. 2013), its association with contemporary views has been non-existent (as far as we are aware). In the SAP literature, Vaara and Whittington (2012) have called for linkages between the strategy-as-practice approach and other perspectives in strategic management research. More recently, Seidl and Whittington (2014), have called on SAP scholars to avoid empirical 'microisolationism', through alignment with 'larger' phenomena that make strategising activity possible (towards taller and flatter ontologies). They contend that a tall ontological position steers us towards typologies of how structures and systems shape what is going on. Considering this, it is the intent of this research to adopt a tall ontology, by blending the SAP micro perspective to the theoretical macro traditions of organisational decline and turnaround. We have adapted a blended approach since we are interested in understanding turnaround strategising practices, which are both individual and social.

\section{Theoretical Framework}

In the context of the foregoing discussion, we coalesce Trahm's et al. (2013) macro model with Jarzabkowski's et al. (2007) micro model, and thus move beyond isolationism by developing a blended theoretical framework that informs our 
empirical study (see Figure 3). The framework portrays the constructs of the turnaround and SAP perspectives, and more importantly, depicts the connection between both approaches via the strategic themes. More specifically, the 'firm actions' branch of the turnaround model can be broadened to encompass these strategic themes, thus moving beyond the narrow scope of actions reported in the extant turnaround literature. Indeed, when examining specific themes, the SAP lens can be utilised to explore episodes of strategy-making, thereby identifying turnaround strategising practices. The 10 strategic themes outlined in Figure 3 emerged from an extension of previous studies (Tansey et al. 2013, 2014) where initially we identified eight strategic themes. As part of an ongoing PhD study, these 10 themes emanated from a comprehensive review of 62 key empirical strategic management studies within the construction project management realm. These studies specifically examined strategies/business practices of construction firms and therefore directly relate to the strategic behaviour of firms in the construction industry. Of the 62 studies, 41 empirical studies tended to group the strategies under various management categories or themes, such as marketing, financial, cost-cutting etc. On this basis, a total of 10 common strategic themes were identified from the 41 empirical studies, with marketing being the most frequently used theme and tendering/procurement being the least frequently used. 


\section{RESEARCH METHOD}

\section{Research Design}

On the assertion of the preceding discussion, the central objective of this study is to explore firms' turnaround strategising practices during the period $2007-2015$. This time period entails periods of both recession (environmental jolt) and growth, thereby allowing for improved generalisability (Morrow et al. 2004). In so doing, the research draws on constructs from the theoretical framework (see Figure 3), including 10 strategic themes, and two theoretical lenses: the organisational decline and turnaround model established by Trahms et al. (2013); and the strategising conceptual framework developed by Jarzabkowski et al. (2007). Indeed, Eisenhardt (1989) argued that increasing the theoretical scope of a study (for example, tying two phenomena together), can increase the conceptual level of the findings and also enhance their internal validity and generalisability. Although we recognise the value an ethnographic approach might have provided, and given that a lot of SAP studies adopt ethno-methodologies (which entail multiple layers of organisational members over time), such techniques are often resource intensive and invasive (Hendry et al. 2010, Jarratt and Stiles 2010). Furthermore, Balogun and colleagues (2003) highlighted limitations relating to the time requirement of initial trust building prior to implementation of such methods, while a number of others authors described, access, confidentially, and sensitivity issues, with an ethnographic approach (Orlikowski 2002, Paroutis and Pettigrew 2007, Hendry et al. 2010). As a result, these limitations encouraged the investigation of alternate methods, namely, a case study approach. The case study approach was deemed appropriate for a number of reasons. First, the approach is most suitable when the sensitivity of the subject of study is high (Regnér 2003), and when the subject matter is an otherwise undocumented process (Noda and 
Bower 1996). Second, case study research is particularly useful when the boundary between the phenomena and context is not well delineated (Yin 2014). Third, the approach provides an 'in-depth' exploration of particular occurrences of phenomenon, and is also suitable for the 'how' and 'why' research questions (Yin 2014, Fellows and Liu 2008). Fourth, several authors have successfully utilised a case study approach across the turnaround and SAP domains. For example, within the turnaround and organisational decline realm, Pajunen (2006) successfully utilised a case study approach to examine stakeholder influences in organisational survival. Regarding SAP research, Hendry et al. (2010), adopted an in-depth qualitative case study approach to explore how boards 'do' strategy. In sum, the research method adopted in this study consists of five exploratory case studies of large Irish construction contractors (see Table 1 for further case details).

\section{Selection Procedures and Cases}

Regarding the sampling strategy, it entailed a three-tiered selection process. Firstly, the selection of the cases was based on a criterion sampling strategy which aligned with the thresholds set out by the European Commission (2005). Here the prerequisite to be satisfied before a firm was contacted for participation in the study was, that it had to have an annual turnover in 2007 greater than $€ 50$ million, thereby deeming them a 'large' firm. Secondly, theoretical sampling entailed the selection of cases who suffered a minimum two year performance decline. Thirdly, convenience sampling allowed the authors to overcome low response rates in applied settings (Abowitz and Toole 2010), particularly given the sensitivity of the required information. Similar to Jarratt and Stiles (2010), leadership networks and industry connections of the researchers (authors) helped identify and access senior executives. The case studies make use of multiple sources of data (both qualitative and quantitative), derived from 
semi-structured in-depth interviews, company documents, and archival documents. Sources of archival data included company annual reports, annual financial statements, director reports, in-house documents and leaflets, general business press, trade journals, and the reports of market research institutions. Subsequently, this material was used to verify the internal information provided from the in-depth interviews. Regarding the selection of interviewees, the following theoretic sampling criteria (Strauss and Corbin 1990) was met: (a) they were 'strategists', who, for part of their formal role and duties, are involved in developing strategic direction (Higgs and Dulewicz 1998); (b) they were in a position to reveal tacit knowledge of strategising practices (Jarratt and Stiles 2010); and (c) they had extensive responsibility and experience of strategy determination. Subsequently, the selected 'strategists' were all senior management; either Chief Executive Officers (hereafter 'CEO'), Managing Directors (hereafter 'MD'), or executive directors, whom were regarded by industry associates as exemplars in driving strategy. Similar to the selection procedures of Jarratt and Stiles (2010), each 'strategist' represented one unit of analysis within the organisation setting (holistic design), however, given that each informant held their current 'executive' position for at least nine years, this enabled them to portray specific strategizing practices at the subunit level (embedded design).

\section{The Empirical Inquiry}

The semi-structured interviews, conducted by this paper's first author, took place between June and September 2015, and typically lasted 1-2 hours, with some as long as 3 hours. The interview guide explored two keys areas - general company information, and turnaround strategising practices pertaining to the period 2007 2015. During the initial stage of the interviews we drew on general information pertaining to the interviewee and the firm (e.g. experience, education, changes in core 
business, geographical spread, organisational structure, and ownership). The second and most prominent stage of the interview started initially by using a broad line of questions which were guided mainly by the strategic themes depicted in Figure 3. At this macro-level, recent and past strategising activities were discussed. Consistent with our theoretical grounding, we also used more focused questions where we drilled down at the micro-level into explanations of how and why specific turnaround strategising practices occurred (i.e. episodes of strategy-making). Given that these decisions and practices took place over a number of years (2007 - 2015), particular attention was also paid to their chronological order and respective interconnections.

On the basis of previous empirical studies (e.g. Price 2003, Tansey et al. 2014) each participant taking part in the study were sent an interview protocol sheet at least one week prior to the interview. This gave the participants time to reflect on the recession which started a number of years ago, and in tandem, to collate any relevant documents or archival data. For transcription purposes and to allow for a consistent flow during the interview discussion, each interview was recorded (written agreement was obtained from participant's) and transcribed verbatim, yielding 77,423 words of information. To ensure construct validity, each transcript was returned and verified by the participants (Yin 2014). Where required, follow-up telephone interviews (with the interviewees and other senior management) were conducted in order to seek clarification of any instances that subsequently emerged as important.

\section{Data analysis}

Drawing on interview transcripts, audio files, company documents and case notes, we prepared five case narratives, which were then uploaded onto Computer Assisted Qualitative Data Analysis Software (CAQDAS). Before case study analysis was conducted, an analytical strategy had to be firstly developed. Accordingly, the analysis 
was guided by two general analytic strategies proposed by Yin (2014): (1) relying on theoretical propositions (deductive), i.e. theoretical framework, and (2) working the data from the ground up (inductive). This abductive approach (Blaikie 2000) was thus employed iteratively throughout the process. On the premise of the general analytic strategy for this study, the first cycle coding method adopted consisted of 'eclectic coding', which best fits as an exploratory method (Saldana 2013). At this stage, the 10 strategic themes represented in Figure 3 were used as the sensitising concepts or organising categories (see Figure 4 for coding structure). Similarly, in the general strategic management domain a number of authors have successfully used deductive strategic themes/categories for coding their respective data (e.g. Burgelman 1983, Mirabeau and Maguire 2014). The subsequent stage entailed second cycle coding methods, which involve 'some rearrangement and reclassification of coded data into different and even new categories' (Saldana 2013, p. 11). During this stage, the detailed coding from the first cycle were then compared at a more conceptual level and continuously modified (Denscombe 1998). Similar to Paroutis and Pettigrew (2007), reference back to the turnaround and SAP literature helped us refine and sharpen our initial concepts, thereby resulting in the emergence of 16 categories (see Figure 4). The final stage in the analytical process is post-coding and pre-writing, which incorporates multiple categories becoming condensed into more streamlined categories. Here the data can be structured/processed in several ways, e.g. sequential order, taxonomy, tabular displays, or networks (Miles and Huberman 1984, Saldana 2013). In this regard, tabular displays were used for presenting the data (see Table 2), as they tend to lead to a portrayal of important patterns of within-case similarities and across-case differences (Eisenhardt 1989). Given that the predominant cause of organisational decline was external, in the form of the 2007 economic recession 
(which in-turn caused an industry contraction-based decline), the data presented in

Table 2 is focused around three main branches: response factors, firm actions, and performance outcomes. 


\section{FINDINGS}

After clarifying our research method, in this section we focus on turnaround strategising practices that were common across all the case firms (similar to analytical methods adopted by Dameron and Torset 2014). More specifically, Table 2 illustrates certain marketing, organisational/managerial, cost/asset retrenchment, and tendering/procurement practices which were common across the cases. However, due to space restrictions, the extent of the analysis under the 'firms actions' branch will be centred on two main categories: marketing (new international and domestic markets), and cost/asset retrenchment (cost retrenchment). Before discussing the three main branches (i.e. response factors, firm actions, outcomes), we firstly provide a chronological depiction of the turnaround strategies for the five case firms. Regarding the 'firm actions' branch, we follow a first-order and second-order analysis approach (similar to Gioia and Chittipeddi 1991, Paroutis and Pettigrew 2007) to present our findings. The first order findings provide a time-sequential narrative of the turnaround strategies for the five case firms during the period 2007-2015, and reveal insights about the development of such practices over time. Using the SAP lens, we then establish second order explanations of our findings, which help us explain in more detail how and why turnaround strategising practices were developed over time (i.e. episodes of strategy-making). In order to provide a chronological representation of firms' turnaround strategies and turnover during the period $2007-2015$, we developed graphical plots for each of the five cases; namely, Figures 5 to 9. Under each figure, attention is also paid to a brief company overview.

Case firm A is a large building and civil engineering firm that has grown steadily from a small Irish local builder to a well diversified, international construction firm operating across the UK, Europe, and the Middle East. Figure 5 illustrates a 72\% 
contraction in turnover over a six year period (2007 - 2013) for Case A. Regarding employee numbers the firm had to reduce its workforce by $70 \%$ during the period $2007-2014$.

Case firm B is a large international construction company operating within the civil and building sectors across Ireland, Europe, and the Middle East. Figure 6 depicts a $51 \%$ decline in turnover over a four year period $(2007$ - 2011) for Case B. In relation to employee numbers the firm cut its workforce by $43 \%$ between the years 2008 2012.

Case firm $\mathrm{C}$ is a large building company operating predominately in Ireland, and more recently in the UK. The company has increased its sectoral presence to include; healthcare, education, commercial, retail, industrial, and residential. Figure 7 exhibts an $83 \%$ decrease in turnover over a two year period (2008 - 2010) for Case C. During the same period, the firm reduced its workforce by $64 \%$.

Case firm D is a large building company that operates within the building sector across Ireland, UK, and the Middle East. The company has completed a portfolio of projects across a number of sectors including; commercial, residential, restoration, industrial, pharmaceutical and healthcare. Figure 8 highlights a $79 \%$ deterioration in turnover over a three year period (2008 - 2011) for Case D. Regarding employee numbers the firm reduced its workforce by $77 \%$ between the years $2007-2012$.

Case firm $\mathrm{E}$ is a large civil engineering contractor that has grown steadily from a small local Irish plant hire and civil engineering firm, to a large diverse civil engineering contracting company. Figure 9 demonstrates a $50 \%$ contraction in turnover over a three year period $(2009$ - 2012) for Case E. During the period 2008 2012 , the firm had to scale down its employee numbers by $45 \%$. 


\section{Response Factors}

The key response factors that form the interface between the cause of decline and the actions taken to reverse the decline include; stakeholder influences, stakeholder relationships, managerial cognition, and luck (see table 2). Considering stakeholder influences. In our study, the case firms reported a number of changes to their prerecession tendering/procurement practices - actions that were mainly instigated by stakeholder influences. For instance, during the recession key suppliers had an important position and had high influence over focal organisations such as main contractors and subcontractors - resource dependence based influence (cf. Pajunen 2006). Due to financial losses suffered from unpaid accounts of bankrupt construction firms, suppliers started demanding upfront payments directly from the main contractor, and thus bypassed subcontractors due to their poor credit history and dwindling cash flow. The Government also held an important position and exerted high influence by way of introducing the new Government Construction Contracts Committee (hereafter 'GCCC') contract in 2007 - network position based influence (cf. Pajunen 2006). This new suite of public contracts tended to exacerbate below-cost tendering practices, which subsequently fuelled disputes and created adversarial relations across the industry. Stakeholder relationships were also found to be a key factor in triggering certain firm actions, particularly regarding marketing practices (see table 2). For example, Case $\mathrm{C}$ exploited its existing relationships with industry professionals (e.g. architects and engineers) to augment diversification into the UK market. On the other hand, Case B availed of ready-made human resources from distressed firms by utilising their relational assets, and subsequently were able to expand into new domestic markets. 
The case firms' perception and interpretation of the environment (i.e. managerial cognition) was also found to have a profound effect on the respective actions taken. More specifically, management's awareness of decline and their perception of the declines severity, were found to have an effect on the timing and intensity of actions taken (see table 2). For instance, Case C, who were exposed to the collapsing property market (which started declining in 2007), perceived a significant decline in turnover, and thus were quick to initiate an aggressive retrenchment response in 2008. On the other hand, Case B, whose predominant market share was in civil engineering (approx. 67\% in 2008), and whom at the time didn't perceive the recession going beyond 2010, waited until 2009 to instigate a more complaisant retrenchment response. The findings also illustrated the importance of 'luck' in shaping certain firm actions (see table 2). Strategic opportunities can sometimes come as a surprise, and can be attained through the manifestation of a firm's good fortune and luck, rather than its ability to anticipate and construe such opportunities (Barney 1986). For instance, on its diversification endeavours into the Scottish market, Case E tried in vain to pre-qualify with a sophisticated public client. Through good fortune and luck, they were approached by an Irish contractor, and subsequently were successful with their joint venture (hereafter 'JV') bid.

\section{Firm Actions}

\section{Marketing}

New international markets. During the term 2007 - 2012, all cases diversified internationally (see Table 2); mainly into the UK, Poland, and the Middle East. What was particularly interesting was the time pattern of UK market entry. For instance, Cases A and D, who previously had some international experience, were first to 
expand in 2009; diversifying one year after suffering a sharp decline in turnover. Case E followed a similar pattern, diversifying into the UK market in 2010 , one year into a declining turnover period. However, for Case E, the start of turnover decline was delayed until 2009 due to the longevity of large civil contracts that they had secured pre-recession. Interestingly, Case firm C, who suffered the steepest decline in turnover (83\%), didn't enter the UK market until 2012. This was partly attributable to senior management's perception of the environment, and also by the fact that they focused all their resources on improving their market share in the public building works sector in Ireland. Entry into the Polish and Middle Eastern markets followed a certain pattern for Case A and E, with both firms entering the markets one year after their UK market entry. Nonetheless, diversification into the Polish market proved ill-fated for both firms, with both having to retract and both suffering severe financial losses. Cases A and E cited; payment problems, a poor dispute process, and their Polish JV partner going bankrupt, as reasoning behind the withdrawal actions.

Analogous with a declining domestic construction sector, several cases described other reasons for diversifying, including; client led opportunities, retaining staff, following competitors, and future proofing the business. What was particularly interesting within the 'practice' of internationalisation, was the 'praxis' of how the case firms actually diversified into the UK market. For instance, Case E seemed to win small public civil contracts fairly easily, by simply siphoning through e-tenders for opportunities. On the other hand, gaining a foothold with a sophisticated client like Transport Scotland for larger projects ended up an arduous process; however, it was unexpectedly achieved through 'luck'. With this particular client, the firm had previously tried to pre-qualify on four occasions, but was unsuccessful. Following initial rejection, the firm would attend the debrief meetings and thus make the 
respective changes for the next prequalification, however, another problem would arise. Ultimately, a large Irish contracting firm, whom had already forged relations with Transport Scotland (luckily pre-recession), approached Case E 'out of the blue' about a possible JV. The resulting JV partnership successfully prequalified for a large infrastructure project, and subsequently won the contract.

New domestic markets. Regarding entry into new domestic markets, all of the five case firms seemed to be prominent in this respect (see Table 2). For example, in response to a declining industry, Case B quickly expanded its presence nationally in 2008, whilst also setting up a small works division to encompass a wider project scope. Moreover, in order to gain expertise and knowledge in pricing mechanical and electrical (hereafter M\&E) works, Case B set up its own services division in 2009. Case $\mathrm{C}$ also reacted to a deteriorating construction market, deciding to enter the evolving public sector design and build (hereafter D\&B) market in 2010; a time when their turnover reached its lowest level. In a similar vein, Case E started to look at smaller public works (for example, bridge rehabilitation) once their large civil projects ended in 2010. Indeed, when their turnover reached its lowest level in 2012, they focused on the resurrected private sector, where they secured their first enabling works contract for an industrial project.

Case firm B provided an interesting example regarding the 'practice' of domestic reorientation, and in particular, the 'praxis' of how firms actually form new divisions. For example, in relation to setting up their small works and services divisions, the firm utilised their relational assets and were quick to avail of ready-made human resources from a bankrupt building firm, and a bankrupt M\&E firm. More specifically, one of the directors who had previously worked with the bankrupt building firm before the recession, saw this situation as an emerging opportunity, and thus employed 
management staff who had previous experience in small building works. Given that larger projects were tailing off, the small works division offered the firm a 'foot in the door' with new clients, particularly those with older building who were regularly maintaining/renovating them. Through constant environmental scanning across networks of stakeholders, Case B also identified the bankruptcy of an M\&E firm as an opportunity to obtain experienced staff and thus build a new services division. As a result, the firm were now in a position to interrogate prices from large $M \& E$ contractors, and if need be, actually undertake the M\&E part of the contract themselves.

\section{Cost / Asset Retrenchment}

Cost retrenchment. All five case companies engaged in various retrenchment actions during the peiod 2007 - 2015 (see table 2). Case C sustained retrenchment for 8 years, Cases A and B for 7 years, Case D for 6 years, while Case E retrenched for just 4 years. Due to their substantial involvement in the residential and commercial markets, Cases A, C and D were first to instigate cost-cutting measures in 2008. Furthermore, given their high exposure to the 'bursting' property bubble, these three firms tended to be more aggressive in their reductions, with all cutting employee numbers, salaries (10 $-20 \%$ cut), bonuses, and company cars. On the other hand, Cases B and E, who were predominately involved in the civil engineering sector, didn't have to activate a retrenchment response until a year later. Indeed, their retrenchment actions tended to be less aggressive than the other three firms; most likely due to the longevity of the large civil contracts that they had secured pre-recession, and also given their limited exposure to the property market. Moreover, as their large civil contracts started to finish in 2009 and 2010, both firms subsequently started to implement employee cuts, however, salary levels remained the same and were frozen until 2015. On a more 
positive note, Cases A, B, D, and E started to increase salaries for the first time in 2015, however, no such increases were reported in Case C. Interestingly, retrenchment actions were reflected in the firms' turnover and profit figures reported during this period.

Depiction of 'how' the case firms retrenched was also evident. In view of this, the smaller firms (Cases C, D, and E) tended to notify staff of imminent cuts through contiguous methods (e.g. personal meetings), while the larger firms (Cases A and B) utilised their annual strategy forums to convey such measures. Case $\mathrm{C}$ provides an interesting example regarding the 'practice' of initial cost retrenchment. When the recession took hold and the turnover started declining, a swift response was made by the MD, directors, and the financial controller to make drastic cuts. This praxis entailed each director visiting every site in their region over a two week period, and subsequently meeting all staff members on an individual basis to communicate the respective retrenchment measures. These initial actions entailed a $10-20 \%$ reduction in salaries at all levels, a 'selective' 20\% reduction in human resources (approx. 30-40 staff), cuts in bonuses, and a dramatic decrease in company vehicles. Within the next 4-6 months as projects finished, selective human resource reductions continued with the elimination of a layer of middle management, which included contracts managers and senior surveyors. For those who were lucky enough to be kept, they were demoted back to being a project manager or project surveyor. This resulted in a reconfiguration of the organisational structure, with structure following strategy, and subsequently with directors now having to deal directly with project managers and project surveyors on a site-level. In order to cope with this revised pattern of management, staff (survivors) had to work longer hours to deal with the respective increase in workloads. On foot of increasing turnover, during 2014 and 2015 the firm were in a position to 
reinstate the layer of middle management. Regarding reductions in human resources across all the case firms, a number of firm-clearing mechanisms were evident; initial wave of lay-offs, lay-offs as projects finished, temporary lay-offs, redundancies, and natural wastage through retirements. Even though a key objective for all the case firms was to try and maintain staff, Cases A, C, and D reduced employee numbers by an average of $70 \%$, while Cases B and E reduced numbers by $44 \%$. Subsequently, the majority of case firms reported increases in employee numbers from 2012 onwards.

\section{Outcomes}

During the period 2007-2015, all case firms (except Case C) underwent at least three consecutive years of turnover decline. Although Case $\mathrm{C}$ suffered turnover decline for only two years, its decline was the steepest recorded across all the firms $(83 \%$ decline). In terms of profitability, the data confirmed that all cases underwent at least two successive years of decline. Interestingly, it was Case firm A that seemed to be under the most financial stress during the period; encountering simultaneous declines in turnover and profit for six consecutive years (2007-2013). In fact, Cases A, C, and D (undertook more aggressive cost and asset retrenchment) attained only 'partial turnaround success'; while in contrast, Cases B and E (adopted less aggressive measures) achieved 'turnaround success' during the period 2007-2015 (see Table 2). More specifically, Cases A, C and D (predominately building based) reported turnover figures for 2015 as being 45-70\% off their peak values, whilst profit levels for 2015 were below pre-downturn levels. In contrast, Cases B and E (predominately civil based) reported turnover figures for 2015 as being only $18 \%$ off peak levels, whilst profit levels for 2015 actually exceeded pre-downturn levels. 


\section{DISCUSSION}

Seidl and Whittington (2014) argued for protection against 'micro-isolationism', thereby extending the scope of SAP scholarly towards taller and flatter ontologies. In this study will have drawn on a tall ontology by linking micro-level strategising to the larger macro-level phenomena of organisational decline and turnaround. In so doing, we undertook a qualitative evaluation of the turnaround strategising practices of five large Irish contractors over the period $2007-2015$. Our findings were found to resonate particularly well with the two theoretical lenses, and therefore offers unique insights into episodes of strategy-making during an environmental jolt. In particular, cost retrenchment was found to be the most defensive action taken, while internationalisation was found to be the most offensive action taken during the period. In order to portray the fundamental building blocks of our tall ontology, we developed a turnaround strategising process model (see Figure 10) that integrates our findings, and thereby makes notable contributions to knowledge.

\section{Turnaround Strategising Process Model}

The model presented in Figure 10 demonstrates the patterns and actions that firms undergo in achieving turnaround success or partial turnaround success during an environmental jolt. In brief, the case firms' performance deteriorated in tandem with an industry contraction-based decline that was caused by an environmental jolt (i.e. 2007 economic recession). In order to halt or reverse the decline, a combination of internal and external response factors precipitated the firm actions to be taken. Indeed, the adopted practices - their intensity, strategy-making episode, and subsequent microlevel praxis - were all shaped and configured by the firms' socially embedded response factors (e.g. path dependency, relationships, etc) that were formed pre- 
recession, and also by the newly integrated response factors (e.g. severity situation, competitive position, slack resources etc) that were instigated as a result of the environmental jolt. Our conceptualisation of the firm actions part of the model avoids modelling operational and strategic reorientation practices as rigid time sequential, rather they are portrayed as occurring simultaneously often impacting on one another. In order to capture the complexity of 'time' in terms of multiple practices, concurrencies and patterns, we provide an extension to the firm actions part of the turnaround strategising process model in the form of Figure 11. This extended process model integrates both cost retrenchment and internationalisation practices. More specifically, during the performance decline phase, firm actions initially entailed decline-stemming operational actions in the form of cost retrenchment. Following the cost retrenchment initiation period, case firms simultaneously undertook strategic reorientation in the form of internationalisation. During the performance recovery phase, all cases managed to stem the decline and become well established in new international markets, thus permitting the majority of firms to cease cost retrenchment by 2015 . Along with economic performance outcomes at the macro-level, the turnaround strategising process model (Figure 10) also incorporates a micro-level approach to practice outcomes (as recommended by Jarzabkowski et al. 2015), which offers an individualised, proximate result. Importantly, the model depicts the interrelationships and feedback loops between stages, thus underlining the high levels of entanglement across the elements. In sum, case firms that implemented aggressive cost retrenchment, and those who undertook extensive internationalisation failed to turnaround - achieving only partial turnaround success. The following sections focus on elements of the models (Figures 10 and 11) in more detail and forward propositions for future testing. 


\section{Response factors}

The case data confirmed that actions taken to reverse the decline were found to be dependent on a number of factors including; stakeholder influences, stakeholder relationships, managerial cognition, and luck. These findings represent contributions to the turnaround domain by building on Trahms et al. (2013) model, and adding indepth details which have not being readily available in a turnaround context.

Regarding managerial cognition, we illustrated the importance of managerial cognition in shaping turnaround strategising practices, in that, we have confirmed that management's awareness of decline and their perception of the declines severity, were found to have a profound effect on the timing and intensity of actions taken (also found by Furrer et al. 2007). Given the critical role that stakeholders play in the turnaround process, two key dimensions emerged from the data; stakeholder influences, and stakeholder relationships. The case data confirmed that key suppliers had an important resource-dependence based influence over focal organisations, while government exerted high influence through network based power. These findings are therefore consistent with Pajunen (2006), who found the management of stakeholder objectives to be instrumental in accessing and controlling resource flows, thereby aiding firm survival. Additionally, our findings illustrate the importance of stakeholder relationships, which have been found to bolster the continued existence of firms (Oliver 1991). Some case firms for example, exploited existing stakeholder relationships to augment diversification actions, while other firms utilised their relational assets to avail of ready-made human resources from distressed firms. Our findings thus build on research focusing on stakeholder theory (Pajunen 2006, Laplume et al. 2008, Trahms et al. 2013), by illustrating how stakeholder influences and relationships affect and shape turnaround strategising practices. Our study also 
suggests that 'luck' plays a key role in shaping firm actions. For instance, we identified a firm's good fortune and luck in attaining work with a sophisticated public client in Scotland. This relates somewhat to an evolutionary process by which some firms were 'lucky' enough to be in the right place at the right time (cf. Cockburn et al. 2000). Through utilising the SAP micro-lens, other firm-specific (internal) response factors also became apparent across the cases, for example, firm size, organisational slack (level of resources), and path dependency. Similar factors were also suggested by turnaround scholars, although on separate instances. For example, Arogyaswamy et al. (1995) depicted 'level of available slack resources' as a plausible response factor, while Barker III and Mone (1998) found 'firm size' to affect the extent of strategic change. On this basis, it is therefore suggested that response factors form a mutually constitutive dichotomy of both external and internal response factors. This analysis may be summarised in terms of the following propositions:

Proposition 1a: During a prolonged environmental jolt (industry contraction-based decline), different combinations of internal and external response factors directly guide the type and intensity of practices adopted.

Proposition 1b: During a prolonged environmental jolt (industry contraction-based decline), the dynamic combination of internal and external response factors encompass factors that are socially embedded in the firm (those formed prerecession), and those that are newly integrated in the firm as a result of a prolonged environmental jolt.

\section{Firm actions}

Another contribution to the organisational decline and turnaround literature is our empirical illustration of the interplay and timing of operational and strategic actions, 
as depicted in Figure 11. Interestingly, the case data confirmed that the majority of case firms entered a performance decline phase between 2008 and 2011, and subsequently entered a recovery phase during the period $2011-2015$. While the strength of support varied slightly across the cases, the main pattern of findings was that turnaround attempts benefitted from the simultaneous interaction of both operational and strategic actions (concurs with Arogyaswamy et al. 1995 and Trahms et al. 2013); rather than the rigid sequential notion put forward by Pearce and Robbins (1993). The case data confirmed that the two larger contractors initiated a retrenchment response one year after declining turnover, while the other three firms commenced a retrenchment response during the same year that turnover started to decline. This would suggest that firm size affects the speed of response, and also helps sustain decline (also found by Barker and Duhaime 1997). In response to the 2007 economic recession, all case firms tended to initiate cost retrenchment measures during the period 2008 - 2009. Indeed, those case firms who were extensively involved in the residential and commercial sectors, and thus were directly exposed to the property crash, tended to be the first to commence cost retrenchment in 2008. On the other hand, those firms who were predominately involved in the civil engineering sector pre-recession, didn't have to activate a retrenchment response until 2009. These findings are thus consistent with Michael and Robbins (1998), who found that a retrenchment response was best to activate the turnaround process. In the year following their initial retrenchment response, the majority of case firms simultaneously undertook strategic actions in the form of internationalisation, thereby shifting towards objectives of growth and development through strategic reorientation of the firms' market domain. Analogous with this, the three year period $(2009-2012)$ tended to be the most active for the case firms - in terms of new international market 
entry, and in some situations market withdrawal. During the performance recovery phase (2011 - 2015), all case firms managed to 'stop the bleeding' (Bibeault 1982) by maintaining a long-term retrenchment strategy. Concurrently, during this period all cases became well established in at least one new international market, thereby enabling the majority of firms to cease retrenchment activities during 2014 - 2015. Our findings also refute Robbins and Pearce (1992) assertion that retrenchment is often a short-term strategy; rather the data strongly confirms that retrenchment is more long-term, particularly during a severe and prolonged environmental jolt, with contractors maintaining cuts for an average of 6.5 years. Essentially, the 2007 global recession was the worst environmental jolt since the great depression of the 1930s (Tansey et al. 2014). This analysis may be summarised in terms of the following propositions:

Proposition 2: During a prolonged environmental jolt (industry contraction-based decline), retrenchment is used to activate the turnaround process.

Proposition 3: Firms speed of retrenchment response to an industry contraction-based decline is dependent on firm size.

Proposition 4a: Firms that are primarily building orientated when entering an environmental jolt, and who are subsequently exposed to a collapsing property market, are first to instigate cost retrenchment.

Proposition 4b: Firms that are predominately involved in civil engineering works when entering an environmental jolt, and who are subsequently more insulated and protected from competitive pressures, are slower at instigating cost retrenchment. 
Proposition 5: During a prolonged environmental jolt (industry contraction-based decline), the three year period following cost retrenchment initiation is the most active era in terms of new international market entry and exit.

Proposition 6: During a prolonged environmental jolt (industry contraction-based decline), the simultaneous interaction of both operational actions and strategic actions creates recovery.

Proposition 7: During a prolonged environmental jolt (industry contraction-based decline), cost retrenchment is a long-term strategy.

Additionally, our findings contribute to the SAP literature by identifying contextually meaningful patterns within episodes of strategy making (similar to Jarzabkowski and Wilson 2002). In particular, our findings illustrate micro-level strategising praxis within the practice of cost retrenchment and internationalisation. To aid our discussion and to further supplement our models, a summary of the main findings including a comparison of strategic reorientation actions vs. operational actions is illustrated in Table 3.

Strategic reorientation - Internationalisation. Internal response factors such as the level of resources and the severity situation, can sometimes pressurise firms to try and turn around performance quickly; often resulting in extensive strategic reorientation without sufficient appraisal. This was particularly evident with Case firm A, who was in a 'high severity' situation, and who undertook three large infrastructure projects in Poland, all at the same time. Organisational slack may also have played a part in this downfall, as senior management sometimes use slack to pursue their own goals and thus engage in inappropriate strategies such as excessive internationalisation (Jensen and Meckling 1976). In this case, internationalisation was inductive in nature and was 
achieved through the exploration of new markets and by sense-making (cf. Weick 1995) on a large scale. Given the difficulty of absorbing the costs of strategic change, the firm had to withdraw from Poland, and as a result, suffered severe financial losses (€50-€60m) that ended up pushing the declining firm closer to failure. These findings align with Barker and Duhaime (1997), who stressed that extensive strategic reorientation during an industry contraction-based decline can be quite precarious for declining firms, pushing them towards bankruptcy. For those firms seeking private building works in the UK market (e.g. Cases C and D), strategic reorientation was dependent a number of external response factors, predominately stakeholder relationships and the firm's path dependency (cf. Teece et al. 1997). On this basis, diversification was abductive in nature, and was realised through the practice of exploiting existing relationships (deductive strategy making), and also through probing of the environment and exploration of new markets (inductive strategy making) (cf. Regnér 2003). Furthermore, praxis entailed a multitude of practitioners interrogating industry boundaries - scrambling to contact clients, architects, and professional quantity surveyors whom they had worked with before in Ireland, and who had diversified into the UK market also.

On the other hand, for those firms seeking public civil works (e.g. Case E) in the UK, strategic reorientation was dependent on good fortune and luck. In this case, diversification relied more on exploratory and inductive everyday activities, which for instance, entailed quantity surveyors siphoning through E-tenders to identify opportunities. This inductive approach seemed crucial for strategy creation (also found by Johnson and Huff 1998); with small scale sensemaking of 'trying-out' enabling the firm to secure a stable foothold in the market. Although this was initially the pattern for winning smaller contracts, success regarding larger projects also 
entailed inductive strategy making. More specifically, strategy making mechanisms consisted of 'informal contacts and encounters' (cf. Regnér 2003), attained through a combination of luck and reputation. In this sense, the firm had built up a good reputation in the Scottish market (through a number of successful small projects) and were equally 'lucky' to have been approached by an established contractor with a view to joint venturing on a large contract. In attending closely to praxis, we distinctively build on the strategy making work of Regnér (2003) by illustrating that successful international diversification can be achieved through a combination of exploitation and exploration (abductive approach), or through exploration alone (inductive approach). This analysis may be summarised in terms of the following propositions:

Proposition 8a: During a prolonged environmental jolt (industry contraction-based decline), firms that are in a high severity situation with ample organisational slack, pursue extensive internationalisation.

Proposition 8b: During a prolonged environmental jolt (industry contraction-based decline), firms that pursue extensive internationalisation are unsuccessful in turning around; pushing them closer to failure.

Proposition 9a1: During a prolonged environmental jolt (industry contraction-based decline), successful internationalisation involves a cautious, well-appraised, nonextensive strategic reorientation; which is realised through an abductive approach.

Proposition 9a2: During a prolonged environmental jolt (industry contraction-based decline), successful internationalisation involves a cautious, well-appraised, nonextensive strategic reorientation; which is realised through an inductive approach involving small scale sensemaking. 
Proposition 9b: During a prolonged environmental jolt (industry contraction-based decline), unsuccessful internationalisation is a result of extensive strategic reorientation; which is realised through an inductive approach involving large scale sensemaking.

Operational - cost retrenchment. Internal response factors such as a firm's closeness to break-even, and management's perception of the decline severity, can dictate the aggressiveness of cost retrenchment responses. Furthermore, external response factors such as a firm's main industry sector (competitive position), and its respective path dependency, also influence a firm's retrenchment response. Considering this, aggressive cost retrenchment was evident with regard to Cases A, C and D, particularly given their substantial involvement in the residential and commercial sectors. On the other hand, Cases B and E were predominately involved in the civil sector, and therefore tended to be less aggressive with their retrenchment response. For all cases, cost retrenchment was deductive in nature, and was based on deliberate 'practical coping' measures aimed specifically at reducing costs and thereby stemming the decline. Interestingly, firms who undertook aggressive cost retrenchment attained only partial turnaround success, while those who adopted less aggressive measures, achieved turnaround success. These findings are consistent with those of Nixon et al. (2004) and Pearce and Michael (1997), who also found that a serious emphasis on retrenchment and downsizing actions led to poorer performance. This final analysis may be summarised in terms of the following propositions:

Proposition 10: Cost retrenchment during a prolonged environmental jolt (industry contraction-based decline) is deductive, and is achieved through deliberate practical coping actions aimed at stemming the decline. 
Proposition 11: During a prolonged environmental jolt (industry contraction-based decline), excessive levels of cost retrenchment have a negative impact on firm performance, and therefore hamper turnaround attempts.

Proposition 12: Firms successfully turning around from a prolonged environmental jolt (industry contraction-based decline) display a combination of non-aggressive cost retrenchment actions and non-extensive internationalisation.

\section{CONCLUSIONS}

We have addressed calls in the SAP literature to extend its scholarly towards taller ontologies, and also calls in the turnaround literature to explore the process and microstructure of turnaround strategies in cyclical environments. To achieve this, we adopted a tall ontology by merging research on organisational decline and turnaround, and the strategy-as-practice perspective. More specifically, the central objective of the research was to explore firms' turnaround strategising practices during the period $2007-2015$, by drawing on five exploratory case studies of large Irish construction contractors. Analogous with this, the sub-objectives of the study were: (1) to understand when, how, and why certain turnaround strategising practices occurred during the period; (2) to explore episodes of strategy-making within the practices of internationalisation and cost retrenchment; and (3) to develop a turnaround strategising process model and associated propositions for future testing.

First, our findings reveal that the developed turnaround strategising process model portrayed in Figure 10 provides a solid theoretical foundation for the integration of both the turnaround and SAP lens, and therefore offers a new perspective which differs from past models. In particular, the model introduces the concept of 'time' into a blended turnaround and SAP perspective. Moreover, the extended process model 
presented in Figure 11, captures the complexity of 'time' in terms of multiple practices, concurrencies and patterns. Empirically, both models demonstrate the patterns and actions that firms undergo in achieving turnaround success or partial turnaround success during a severe and prolonged environmental jolt. Furthermore, our turnaround strategising process model highlights that macro and micro levels are indeed linked through practices, thereby confirming Seidl and Whittington's (2014, p.2) notion that for tall ontologies, 'micro-level strategizing praxis depends hierarchically on larger macro structures or systems'. Second, regarding contributions to the turnaround literature, we build on the work of Trahms et al. (2013) by exploring the micro-processes of turnaround strategies. In so doing, we offer new dimensions by introducing the concepts of both internal, and external response factors - in the form of socially embedded and newly integrated response factors. We further conceptualise firm actions by introducing the concept of practice intensity, along with existing theoretical SAP constructs, such as, strategy-making episode, micro-level strategising praxis, and practice outcomes. The main pattern of findings show that turnaround attempts during the period 2007-2015, benefitted best from the simultaneous interaction of both non-aggressive operational actions and non-extensive strategic reorientation. In particular, cost retrenchment was found to be the most defensive action taken, while internationalisation was found to be the most offensive action taken during the period. Indeed, the evidence seems to advocate the influence of both external and internal response factors in triggering actions. The findings show that firms who are predominately involved in civil engineering works when entering an environmental jolt, tend to be more insulated and protected from competitive pressures, and thus turnaround quicker. In contrast, firms who are primarily building orientated when entering a recession, and who are subsequently exposed to a 
collapsing property market, are more vulnerable, and tend to be slower to turnaround their performance. In response to the environmental jolt, all case firms tended to adopt a long-term cost retrenchment strategy (average 6.5 years); initiating retrenchment measures during 2008 - 2009, and ceasing retrenchment measures during 2014 2015. Concurrent with the retrenchment phase, the three year period $(2009-2012)$ following cost retrenchment initiation tended to be the most active era for the cases in terms of new international market entry and in some circumstances, market exit. Indeed, during the performance recovery phase (2011 - 2015), all case firms managed to stem the decline, whilst also becoming well established in at least one new international market. Third, regarding contributions to the SAP literature, our research findings offers unique insights into episodes of strategy-making during an environmental jolt, thereby enabling contextually meaningful patterns to be identified. We distinctively build on the work of Regnér (2003), by illustrating strategy-making episodes within the practices of internationalisation and cost retrenchment, and also by introducing a new 'abductive' approach. Regarding strategising praxis within internationalisation, the five case studies have revealed that successful expansion can be realised through an abductive approach of exploration and exploitation, or through an inductive approach of exploration alone involving small scale sensemaking. In regard to operational actions, the practice of cost retrenchment was found to be deductive in nature across all the cases. On this basis, retrenchment was achieved through deliberate practical coping measures aimed specifically at reducing costs and thereby stemming the decline. Fourth, our findings also show support for other theories in explaining how certain turnaround strategising practices emerged. For instance, regarding Dunning's (2003) OLI paradigm, ownership advantages through resource availability was present across some of the case firms. Indeed, other aspects 
of the OLI theory, such as macro level locational factors (e.g. government policies, competitive intensity) may also have influenced the case firms' international strategic position. Furthermore, Chia and Holt's (2009) emergent notion of 'strategy without design' offers alternate explanations for the findings herein. Regarding diversification into the UK market, strategising praxis also entailed locally embedded, unscripted, coping ingenuities, which encompassed forms of tacit knowing; where the fundamental concern for the case firms was survival.

The investigation of turnaround strategising practices in this study has several limitations. First, given the restriction of the empirical data to five case firms, caution in making generalisations across the industry is clearly recommended. However, Eisenhardt (1989) argued that four to 10 cases are adequate for analytic generalisations. Second, the findings presented here might lack sophisticated psychology techniques (e.g. activity theory frameworks) which provide a platform for analysing more detailed human practices over time. Finally, it is acknowledged that our process model has some limitations, in that, alternative models may become apparent in an extension of this work. Although our model is based on data collected during a period of economic contraction and moderate growth, it is anticipated that the model may need to be adjusted for future changes in internal and external response factors as a consequence of ongoing challenges at micro and macro-environment levels. It could be that growth and intra-organisational development based strategies become dominant during such periods, thereby portraying different interactions and intensities of such practices.

A number of potentially significant directions for future research have been generated from this study, along with some interesting and important research questions. First, non-aggressive cost retrenchment and non-extensive internationalisation may not be 
the only explanation for successful turnarounds reported here. Subsequent research could examine the possibility that some firms turned around because of their idiosyncratic initial conditions (cf. Cockburn et al. 2000) and/or their path dependencies regarding competitive positioning or accumulation of heterogeneous resources (cf. Barney 1991). Additionally, our proposed process model will hopefully encourage scholars to generate more specific and contextually sensitive theories. One direction beyond the scope of the paper, could be to extend the model to include praxis mechanisms, which could offer alternate explanations for practice success. For example, with regard to internationalisation, resource orchestration (cf. Sirmon et al. 2011) and the B-B process model of strategy-making (cf. Mirabeau and Maguire 2014) could offer potential avenues in terms of exploring resource allocation and the use of mobile human resources. Regarding the practical contributions of our study, the process models, tables of turnaround strategising practices, and propositions offered in this study, provide guidance to practising managers for responding to industry contraction-based decline. In particular, the findings provide support for the selection and timing of operational and strategic actions, and their respective effect on turnaround attempts. However, our research suggests that during an environmental jolt, managers should be careful not to destroy the firm's tacit knowledge base through aggressive retrenchment, nor attempt excessive internationalisation in light of organisational slack and high severity situations. 


\section{REFERENCES}

Abowitz, D. A. and Toole, T. M., 2010. Mixed methods research: fundamental issues of design, validity, and reliability in construction research. Journal of Construction Engineering and Management, 136(1), 108-116.

Ambrosini, V., Bowman, C., and Burton-Taylor, S. B., 2007. Inter-team coordination activities as a source of customer satisfaction. Human Relations, 60 (1), 59-98.

Arogyaswamy, K., Barker, V. L., and Yasi-Ardekani, M., 1995. Firm turnarounds: an integrative two-stage model. Journal of Management Studies, 32(4), 493-525.

Balogun, J., Huff, A., and Johnson, P., 2003. Three responses to the methodological challenges of studying and strategizing. Journal of Management Studies, 40(1), 197224.

Balogun, J. and Johnson, G., 2005. From intended strategies to unintended outcomes: the impact of change recipient sensemaking. Organization Studies, 26(11), 1-29.

Barker, V. L. III. and Duhaime, I. M., 1997. Strategic change in the turnaround process: theory and empirical evidence. Strategic Management Journal, 18(1), 13-38.

Barker, V. L. III. and Mone, M. A., 1994. Retrenchment: cause of turnaround or consequence of decline? Strategic Management Journal, 15(5), 395-405.

Barker, V. L. III. and Mone, M. A., 1998. The mechanistic structure shift and strategic reorientation in declining firms attempting turnarounds. Human Relations, 51(10), 1227-1258.

Barker, V. L., et al., 1998. An empirical study of the value of downsizing for firm turnaround. In: D. Ketchen, ed. Advances in Applied Business Strategy. Greenwich, CT: JAI Press, 57-82. 
Barney, J. B., 1986. Strategic factor markets: expectations, luck and business strategy. Management Science, 32(10), 1231-1241.

Barney, J.B., 1991. Firm resources and sustained competitive advantage. Journal of Management, 17(1), 99-120.

Barney, J. B. and Felin, T., 2013. What are microfoundations? The Academy of Management Perspectives, 27(2), 138-155.

Bibeault, D. G., 1982. Corporate Turnaround: How Managers turn Losers into Winners. New York: McGraw-Hill.

Blaikie, N. W. H., 2000. Designing Social Research: The logic of Anticipation. Cambridge: Polity Press.

Brooks, T., et al., 2016. The impact of the recent economic recession on the operation of the NEC contract in Northern Ireland. Construction Management and Economics, 34(6), 393-417.

Brown, J. S. and Duguid, P., 2000. The Social Life of Information. Boston: Harvard Business School Press.

Brown, J. S. and Duguid, P., 2001. Knowledge and organization: a social practice perspective. Organization Science, 12(2), 198-213.

Burgelman, R. A., 1983. A model of the interaction of strategic behaviour, corporate context, and the concept of strategy. Academy of Management Review, 8(1), 61-70.

Chen, R. and Martin, M. J., 2001. Foreign expansion of small firms: the impact of domestic alternatives and prior foreign business involvement. Journal of Business Venturing, 16(6), 557-574. 
Chia, R. C. H. and Holt, R., 2009. Strategy without Design: The Silent Efficacy of Indirect Action. New York: Cambridge University Press.

Chia, R. and Holt, R., 2006. Strategy as practical coping: a heideggerian perspective. Organization Studies, 27(5), 635-655.

Chia, R. and MacKay, B., 2007. Post-processual challenges for the emerging strategyas-practice perspective: discovering strategy in the logic of practice. Human Relations, $60(1), 217-242$.

CIF, 2015. Construction employment - the key figures [online]. Available from: http://bit.ly/1K9S2Nn [accessed 15 October 2016].

Cockburn, I. M., Henderson, R. M., and Stern, S., 2000. Untangling the origins of competitive advantage. Strategic Management Journal, 21(10/11), 1123-1145.

Damerson, S. and Torset, C., 2014. The discursive construction of strategists' subjectivities: towards a paradox lens on strategy. Journal of Management Studies, 51(2), 291-319.

Datta, D. K., et al., 2010. Causes and effects of employee downsizing: a review and synthesis. Journal of Management, 36(1), 281-348.

DeDee, J. K. and Vorbies, D. W., 1998. Retrenchment activities of small firms during economic downturn: an empirical investigation. Journal of Small Business Management, 36(3), 46-61.

Denscombe, M., 1998. The good research guide for small-scale research projects. Buckingham: Open University Press. 
Dess, G. G. and Beard, D. W., 1984. Dimensions of organizational task environments. Administrative Science Quarterly, 29(1), 52-73.

Doh, J. P., 2005. Offshore outsourcing: implications for international business and strategic management theory and practice. Journal of Management Studies, 42 (3), $695-704$.

Dunning, J. H., 2003. The eclectic (OLI) paradigm of international production: past, present and future. In: J. Cantwell and R. Narula, eds. International Business And The Eclectic Paradigm: Developing The OLI Framework. London: Routledge, 1-24.

Dunning, J. H. and Lundan, S., 2008. Institutions and the OLI paradigm of the multinational enterprise. Asia Pacific Journal of Management, 25 (4), 573-593.

Durkheim, E., 1962. Socialism, trs. by C. Slatter. New York: Collier Books.

Eisenhardt, K., 1989. Building theories from case study research. Academy of Management Review, 14(4), 532-550.

European Commission, 2005. The New SME Definition: User Guide and Model Declaration [online]. Available from: http://bit.ly/1fQB9Zu [accessed 15 July 2013]. Fellows, R. and Liu, A., 2008. Research methods for construction. 3rd edn. Oxford, UK: Wiley-Blackwell.

Freeman, S. J. and Cameron, K. S., 1993. Organizational downsizing: a convergence and reorientation framework. Organization Science, 4(1), 10-29.

Furrer, O., Pandian, J., and Thomas, H., 2007. Corporate strategy and shareholder value during decline and turnaround. Management Decision, 45(3), 372-392. 
Gioia, D. A. and Chittipeddi, K., 1991. Sensemaking and sensegiving in strategic change initiation. Strategic Management Journal, 12(6), 433-448.

Hambrick, D. C. and Schecter, S. M., 1983. Turnaround strategies for mature industrial-product business units. Academy of Management Journal, 26(2), 231- 248.

Heidegger, M., 1962. Being and time. Oxford: Blackwell.

Hendry, K. P., Kiel, G. C., and Nicholson, G., 2010. How boards strategise: a strategy as practice view. Long Range Planning, 43(1), 33-56.

Higgs, M. and Dulewicz, V., 1998. Top team processess: does $6+2=10$ ? Journal of Managerial Psychology, 13(1/2), 47-62.

Hofer, C. W., 1980. Turnaround strategies. Journal of Business Strategy, 1(1), 19-31.

Jarratt, D. and Stiles, D., 2010. How are methodologies and tools framing managers' strategizing practice in competitive strategy development. British Journal of Management, 21(1), 28-43.

Jarzabkowski, P., 2004. Strategy as practice: recursiveness, adaptation and practicesin-use. Organization Studies, 25(4), 529-560.

Jarzabkowski, P., 2005. Strategy as practice: An activity-based approach. London: Sage.

Jarzabkowski, P., Balogun, J. and Seidl, D., 2007. Strategizing: the challenges of a practice perspective. Human Relations, 60(1), 5-27.

Jarzabkowski, P., et al., 2015. On the risk of studying practices in isolation: linking what, who, and how in strategy research. Strategic Organization, 14(3), 248-259. 
Jarzabkowski, P. and Wilson, D., 2002. Top teams and strategy in a UK university. Journal of Management Studies, 39(3), 355-381.

Jensen, M. and Meckling, W., 1976. Theory of the firm: managerial behaviour, agency cost and ownership structure. Journal of Financial Economics, 3(4), 305- 360.

Johnson, G. and Huff, A. S., 1998. Everyday innovation everyday strategy. In: G. Hamel, C.K. Prahalad, H. Thomas and D.O. O'Neal, eds. Strategic Flexibility: Managing in a Turbulent Environment. New York: John Wiley \& Sons, 13-27.

Johnson, G., Melin, L., and Whittington, R., 2003. Micro strategy and strategizing: towards an activity-based view? Journal of Management Studies, 40(1), 3-22.

Knopp, T. A., 2010. Recessions and Depressions. 2nd edn. California: ABC CLIO. Laplume, A. O., Sonpar, K., and Litz, R. A., 2008. Stakeholder theory: reviewing a theory that moves us. Journal of Management, 34(6), 1152-1189.

Lim, D. S. K., et al., 2013. Rethinking the effectiveness of asset and cost retrenchment: the contingency effects of a firm's rent creation mechanism. Strategic Management Journal, 34(1), 42-61.

McKinley, W., Latham, S., and Braun, M., 2014. Organizational decline and innovation: turnarounds and downward spirals. Academy of Management Review, 39(1), 88-110.

Meyer, A. D., 1982. Adapting to environmental jolts. Administrative Science Quarterly, 27(4), 515-537. 
Meyer, A. D., Brooks, G. R., and Goes, J. B., 1990. Environmental jolts and industry revolutions: organizational responses to discontinuous change. Strategic Management Journal, 11(4), 93-110.

Michael, S. C. and Robbins, D. K., 1998. Retrenchment among small manufacturing firms during recession. Journal of Small Business Management, 36(3), 35-45.

Miles, M. and Huberman, A. M., 1984. Qualitative data analysis. Beverly Hills, CA: Sage Publications.

Mintzberg, H., 1978. Patterns in strategy formation. Management Science, 24(9), 934948.

Mirabeau, L. and Maguire, S., 2014. From autonomous strategic behaviour to emergent strategy. Strategic Management Journal, 35(8), 1202-1229.

Morrow, J. L., Johnson, R. A., and Busenitz, L. W., 2004. The effects of cost and asset retrenchment on firm performance: the overlooked role of a firm's competitive environment. Journal of Management, 30(2), 189-208.

Morrow, J. L. J. R., et al., 2007. Creating value in the face of declining performance: firm strategies and organizational recovery. Strategic Management Journal, 28(3), $271-283$

Moulton, W. N. and Thomas, H., 1993. Bankruptcy as a deliberate strategy: theoretical consideration and empirical evidence. Strategic Management Journal, $14(2), 125-135$.

Ndofor, H. A., Vanevenhoven, J., and Barker, V. L. III., 2013. Software firm turnarounds in the 1990s: an analysis of reversing decline in a growing, dynamic industry. Strategic Management Journal, 34(9), 1123-1133. 
Nixon, R. D., et al., 2004. Market reactions to announcements of corporate downsizing actions and implementation strategies. Strategic Management Journal, 25(11), 1121-1129.

Noda, T. and Bower, J. L., 1996. Strategy making as iterated processes of resource allocation. Strategic Management Journal, 17(S1), 159- 192.

Oliver, C., 1991. Strategic responses to institutional process. Academy of Management Review, 16(1), 145-179.

Orlikowski, W., 2002. Knowing in practice: enacting a collective capability in distributive organizing. Organization Science, 13(3), 249-273.

Pajunen, K., 2006. Stakeholder influences in organizational survival. Journal of Management studies, 43(6), 1261-1288.

Paroutis, S. and Pettigrew, A., 2007. Strategizing in the multi-business firm: strategy teams at multiple levels and over time. Human Relations, 60(1), 99-135.

Pearce, J. A. II. and Michael, S. C., 1997. Marketing strategies that make entrepreneurial firms recession-resistant. Journal of Business Venturing, 12(4), 301314.

Pearce, J. A. II. and Robbins, K., 1993. Toward improved theory and research on business turnaround. Journal of Management, 19(3), 613-636.

Pheng, L. S. and Hongbin, J., 2006. Analysing ownership, locational and internalization advantages of Chinese construction MNCs using rough sets analysis. Construction Management and Economics, 24 (11), 1149-1165. 
Price, A. D. F., 2003. The strategy process within large construction organisations. Engineering, Construction and Architectural Management, 10(4), 283-296.

Ramanujan, V. and Varadarajan, P., 1989. Research on corporate diversification: a synthesis. Strategic Management Journal, 10(6), 523-551.

Rasche, A. and Chia, R., 2009. Researching strategy practices: a genealogical social theory perspective. Organization Studies, 30(7), 713- 734.

Reckwitz, A., 2002. Toward a theory of social practices: a development in culturalist theorizing. European Journal of Social Theory, 5(2), 243-263.

Regnér, P., 2003. Strategy creation in the periphery: inductive versus deductive strategy making. Journal of Management Studies, 40(1), 57-82.

Regnér, P., 2008. Strategy-as-practice and dynamic capabilities: steps towards a dynamic view of strategy. Human Relations, 61(4), 565-588.

Regnér, P., 2016. Relating strategy as practice to the resource based view, capabilities perspectives and the micro-foundation approach. In: D. Golsorkhi, L. Rouleau, D. Seidl and E. Vaara, eds. Cambridge Handbook of Strategy as Practice. 2nd edn. Cambridge: Cambridge University Press, 301-316.

Robbins, D. K. and Pearce, J. A., 1992. Turnaround: retrenchment and recovery. Strategic Management Journal, 13(4), 287-309.

Saldana, J., 2013. The Coding Manual for Qualitative Researchers. 2nd edn. London: Sage.

Salvato, C., 2003. The role of micro-strategies in the engineering of firm evolution. Journal of Management Studies, 40(1), 83-108. 
Schendel, D., Patton, G. R., and Riggs, J., 1976. Corporate turnaround strategies: a study of profit decline and recovery. Journal of General Management, 3(3), 3-11.

Seidl, D. and Whittington, R., 2014. Enlarging the strategy-as-practice research agenda: towards taller and flatter ontologies. Organization Science, 35(10), 14071421.

Simmel, G., 1974. Individuality and social forms. Chicago: University of Chicago Press.

Sirmon, D. G., et al., 2011. Resource orchestration to create competitive advantage: breath, depth, and life cycle effects. Journal of Management, 37(5), 1390-1412.

Strauss, A. M. and Corbin, J. M., 1990. Grounded theory research: procedures, canons, and evaluative criteria. Qualitative Sociology, 13(1), 3-21.

Sudarsanam, S. and Lai, J., 2001. Corporate financial distress and turnaround strategies: an empirical analysis. British Journal of Management, 12(3), 183-199.

Tan, H. and See, H., 2004. Strategic reorientation and responses to the Asian financial crisis: the case of the manufacturing industry in Singapore. Asia Pacific Journal of Management, 21(1-2), 189-211.

Tansey, P., Meng, X., and Cleland, D., 2013. A critical review of response strategies adopted by construction companies during an economic recession. In: S.D. Smith and D.D. Ahiaga-Dagbui, eds. Proceedings of the $29^{\text {th }}$ Annual ARCOM Conference, 2-4 September, Reading: Association of Researchers in Construction Management, 679689. 
Tansey, P., Spillane, J.P., and Meng, X., 2014. Linking response strategies adopted by construction firms during the 2007 economic recession to Porter's generic strategies. Construction Management and Economics, 32(7-8), 705-724.

Tansey, P. and Spillane, J.P., 2014. Government influence on the construction industry during the economic recession 2007-2013. In: A.B. Raiden and E. AboagyeNimo, eds. Proceedings of the $30^{\text {th }}$ Annual ARCOM Conference, 1-3 September, Portsmouth: Association of Researchers in Construction Management, 1101-1110. Teece, D. J., Pisano, G., and Shuen, A., 1997. Dynamic capabilities and strategic management. Strategic Management Journal, 18(7), 509- 533.

Trahms, C. A., Ndofor, H. A., and Sirmon, D. G., 2013. Organisational decline and turnaround: a review and agenda for future research. Journal of Management, 39(5), 1277-1307.

Tsoukas, H., 2010. Practice, strategy-making and intentionality: A Heideggerian ontoepistemology for strategy as practice. In: D. Golsorkhi, L. Rouleau, D. Seidl and E. Vaara, eds. Cambridge Handbook of Strategy as Practice. Cambridge: Cambridge University Press, 47-62.

Vaara, E. and Whittington, R., 2012. Strategy-as-practice: taking social practices seriously. The Academy of Management Annals, 6(1), 285-336.

Venkataraman, S. and Van de Ven, A. H., 1998. Hostile environmental jolts, transaction set, and new business. Journal of Business Venturing, 13(3), 231-255.

Weick, K. E., 1995. Sensemaking in organizations. Thousand Oaks, CA: Sage. Whittington, R., 1996. Strategy as practice. Long Range Planning, 29(5), 731-735. 
Whittington, R., 2006. Completing the practice turn in strategy research. Organization Studies, 27(5), 613-634.

Wittgenstein, L., 1951. Philosophical investigations. Oxford: Basil Blackwell.

Yin, R. K., 2014. Case Study Research: Design and Methods. 5th edn. Thousand Oaks, CA: Sage. 


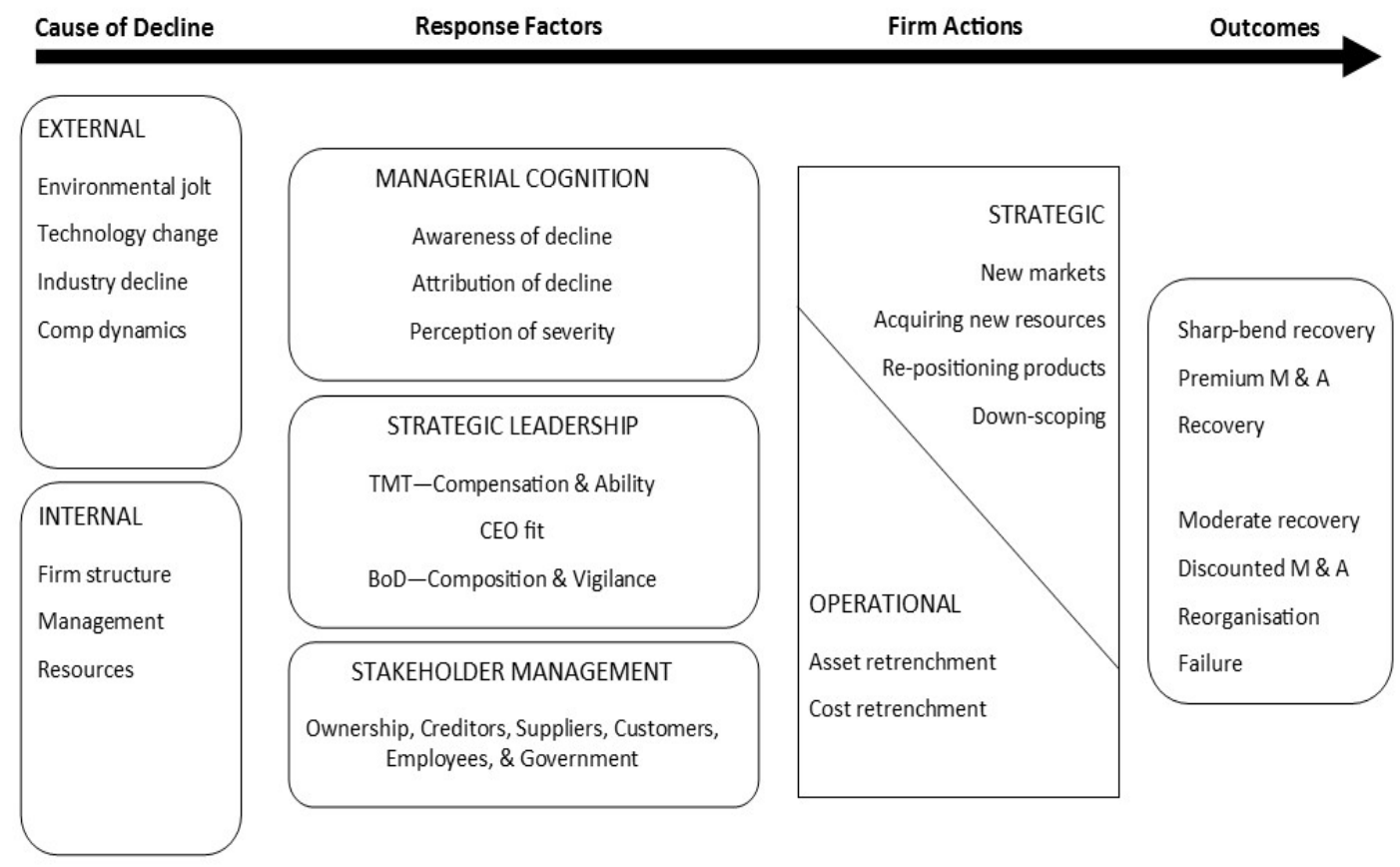

Figure 1 Model of Organisational Decline and Turnaround (Trahms et al. 2013, p.1288) 


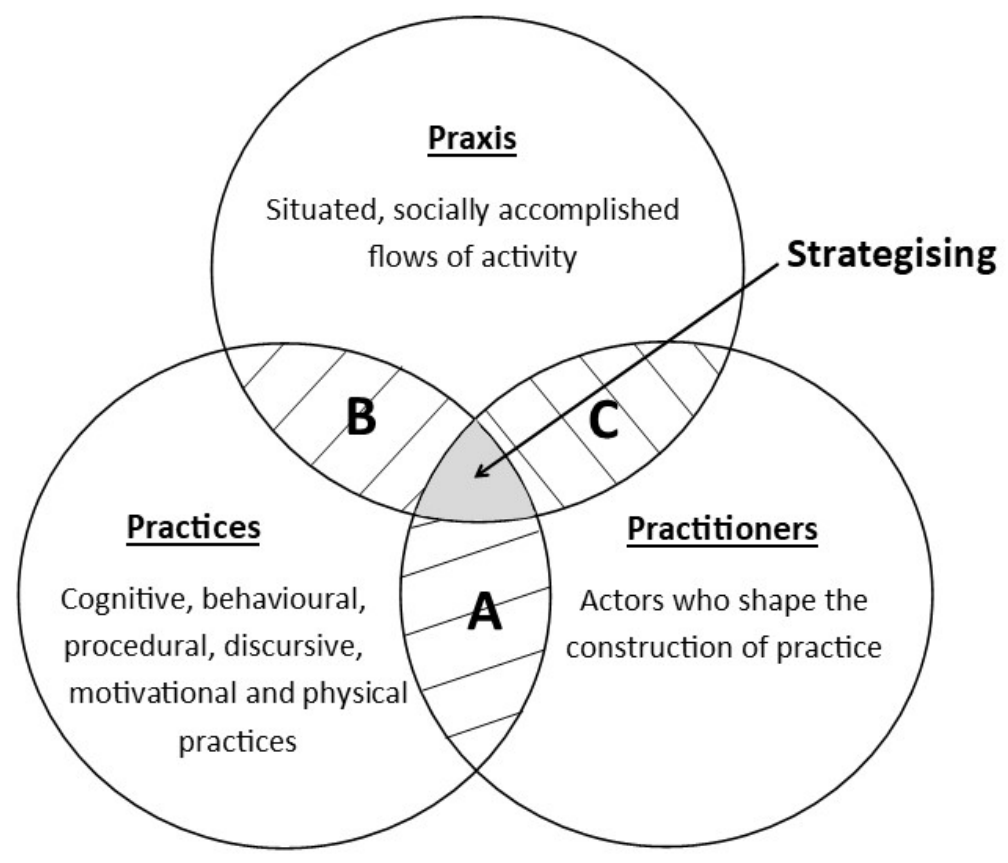

Figure 2 Conceptual framework for analysing SAP (Jarzabkowski et al. 2007, p.11) 


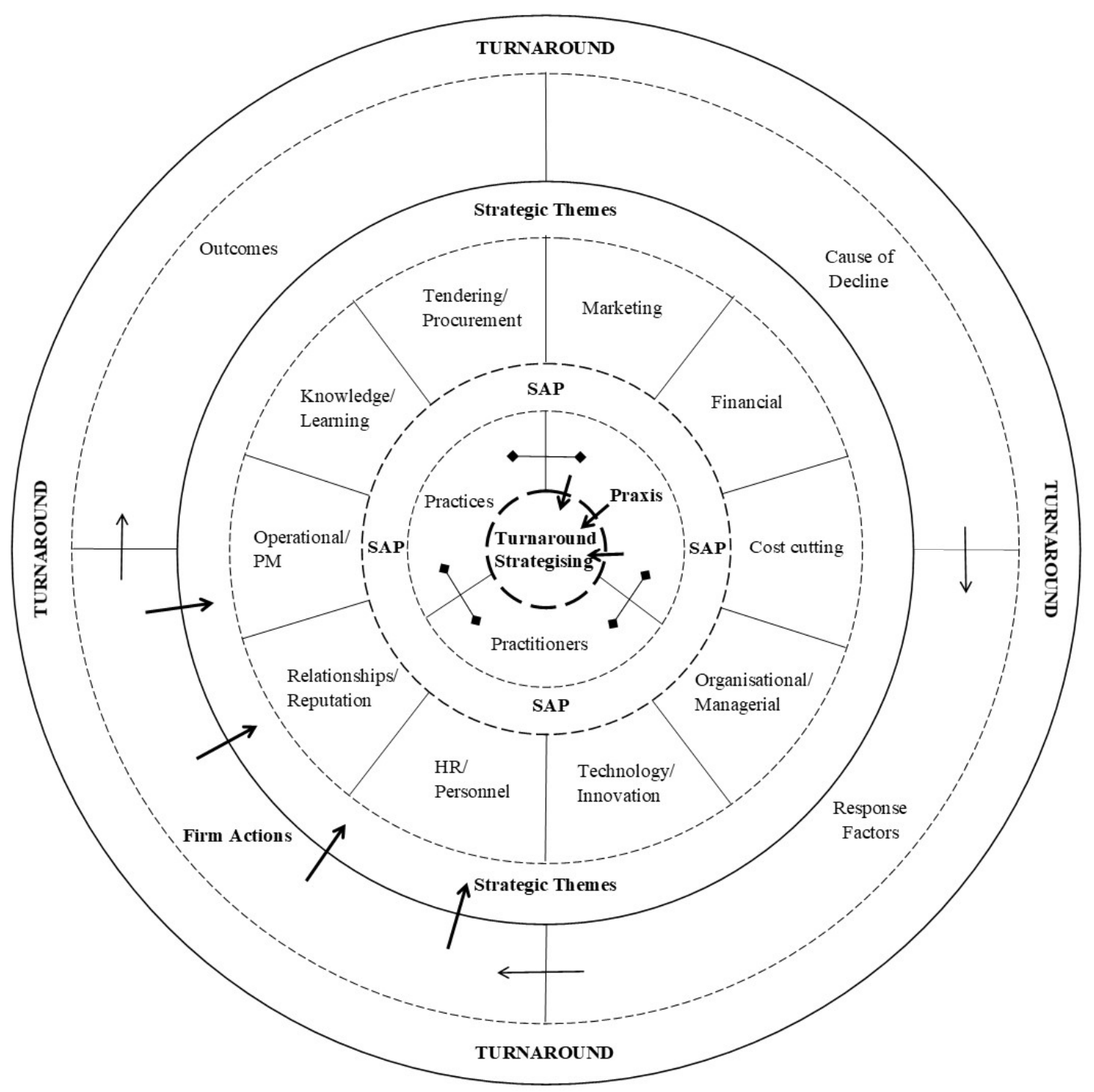

Figure 3 Theoretical framework informing the study 
Table 1 Case descriptions

\begin{tabular}{|c|c|c|c|c|c|c|}
\hline \multirow[t]{2}{*}{ Case } & \multicolumn{2}{|c|}{$\begin{array}{l}\text { Size (Turnover } \\
\text { Index) }\end{array}$} & \multirow[t]{2}{*}{ Sector } & \multicolumn{3}{|c|}{ Main Informants } \\
\hline & 2007 & 2015 & & Position & Experience & Background \\
\hline $\mathrm{A}$ & 100 & 31.4 & $\begin{array}{l}\text { Building / } \\
\text { Civil }\end{array}$ & Director & 27 years & $\begin{array}{l}\text { Quantity } \\
\text { Surveying }\end{array}$ \\
\hline $\mathrm{B}$ & 38.3 & 31.3 & $\begin{array}{l}\text { Building / } \\
\text { Civil }\end{array}$ & Director & 26 years & Civil Engineering \\
\hline $\mathrm{C}$ & 14.5 & 8.9 & Building & Director & 20 years & Civil Engineering \\
\hline $\mathrm{D}$ & 14.4 & 7.8 & Building & Managing Director & 25 years & $\begin{array}{l}\text { Quantity } \\
\text { Surveying }\end{array}$ \\
\hline $\mathrm{E}$ & 4.5 & 5.7 & Civil & Director & 23 years & Civil Engineering \\
\hline
\end{tabular}

Notes: Highest turnover recorded in 2007 relates to Case A, and equates to a turnover index value of 100. 


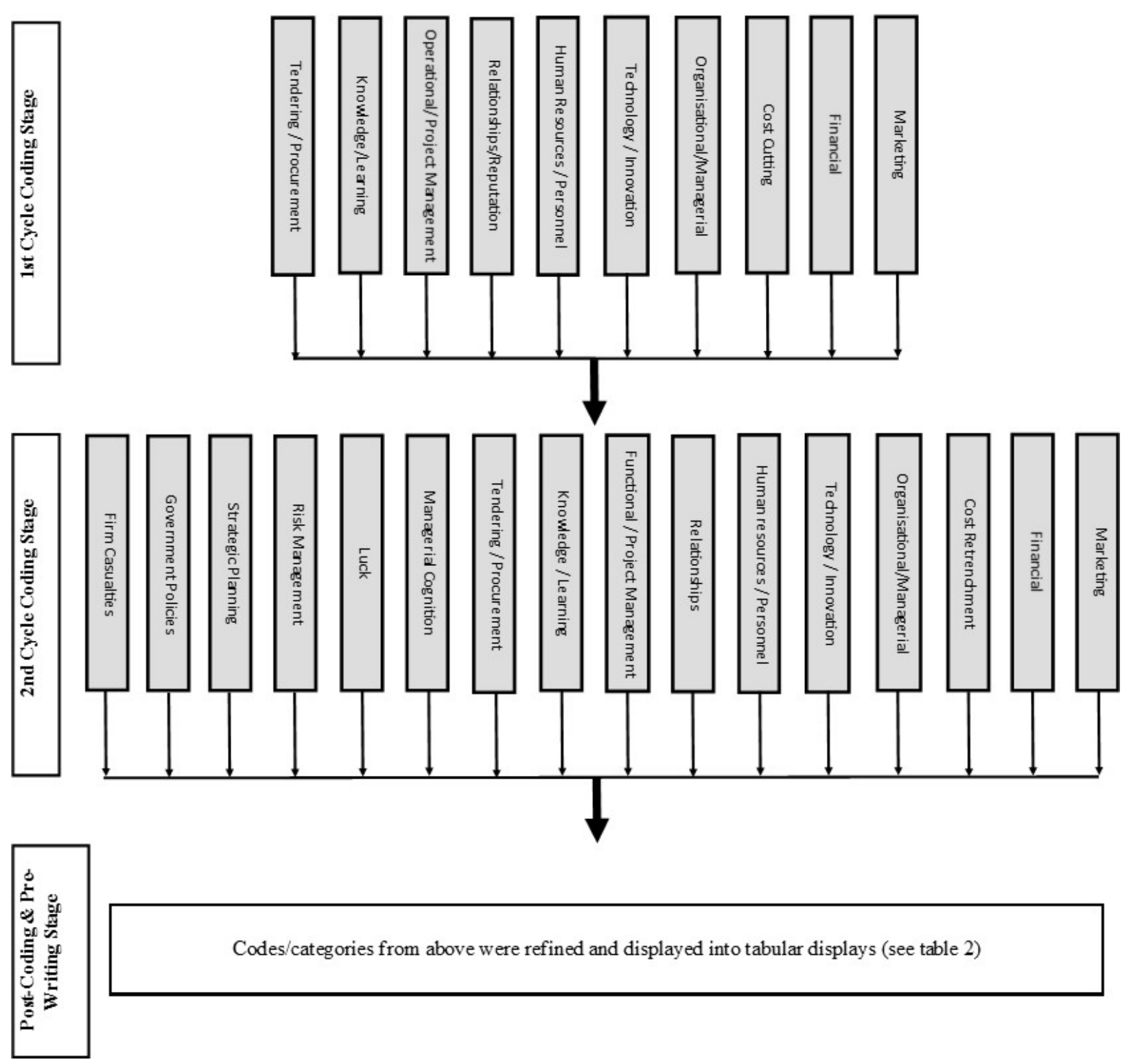

Figure 4 Coding Structure 
Table 2

$2007-2015$

\begin{tabular}{|c|c|c|c|c|c|c|}
\hline Response Factors & Firm Actions & $\mathbf{A}$ & $\mathbf{B}$ & $\mathbf{C}$ & $\mathbf{D}$ & $\mathbf{E}$ \\
\hline & Strategic & & & & & \\
\hline \multirow{8}{*}{$\begin{array}{l}\text { SR (clients, architects/engineers), } \\
\text { Managerial cognition, Luck }\end{array}$} & Marketing & & & & & \\
\hline & New international markets & $\mathrm{X}$ & $\mathrm{X}$ & $X$ & $\mathrm{X}$ & $\mathrm{X}$ \\
\hline & New domestic markets & $\mathrm{X}$ & $\mathrm{X}$ & $\mathrm{X}$ & $X$ & $\mathrm{X}$ \\
\hline & Promotional Actions: Changed website & $\mathrm{X}$ & $\mathrm{X}$ & $\mathrm{X}$ & & $\mathrm{X}$ \\
\hline & New brochures & & & $\mathrm{X}$ & & $\mathrm{X}$ \\
\hline & Sponsorship & & & $\mathrm{X}$ & $\mathrm{X}$ & \\
\hline & Rebranding & $\mathrm{X}$ & $\mathrm{X}$ & & & \\
\hline & Business development team & & & $\mathrm{X}$ & & $\mathrm{X}$ \\
\hline \multirow{5}{*}{$\begin{array}{l}\text { SI \& SR (banks), Managerial } \\
\text { cognition }\end{array}$} & Organisational/Managerial & & & & & \\
\hline & Senior appointments & $\mathrm{X}$ & $\mathrm{X}$ & $\mathrm{X}$ & $\mathrm{X}$ & $\mathrm{X}$ \\
\hline & Restructuring & $\mathrm{X}$ & $\mathrm{X}$ & $\mathrm{X}$ & $\mathrm{X}$ & $\mathrm{X}$ \\
\hline & Strategic planning & $\mathrm{X}$ & $\mathrm{X}$ & & & \\
\hline & New offices & & $\mathrm{X}$ & $\mathrm{X}$ & & $\mathrm{X}$ \\
\hline \multirow{4}{*}{$\begin{array}{l}\text { SI \& SR (banks, suppliers, clients, } \\
\text { subcontractors), Managerial cognition }\end{array}$} & Financial & & & & & \\
\hline & New financial reporting/monitoring & & $\mathrm{X}$ & & $\mathrm{X}$ & $\mathrm{X}$ \\
\hline & Financial health - cash reserves & & $\mathrm{X}$ & $\mathrm{X}$ & $\mathrm{X}$ & \\
\hline & Stringent payment practices & $\mathrm{X}$ & $\mathrm{X}$ & $\mathrm{X}$ & $\mathrm{X}$ & $\mathrm{X}$ \\
\hline
\end{tabular}

Managerial cognition

SI (government, suppliers, clients, competitors, subcontractors),

Managerial cognition

SI (government, clients, industry dynamics)

SI (government, clients, industry dynamics)

\section{Operational}

Cost / Asset Retrenchment

Cost retrenchment: Salaries/wages Employee no's.

Bonuses

Asset retrenchment Cars/vehicles

Tendering / Procurement

$\begin{array}{lllll}\text { X } & X & X & X & \text { X } \\ X & X & X & X & X \\ X & X & X & X & \\ X & & X & X & \\ X & X & X & & \end{array}$

Below cost tendering

New joint ventures

New tendering practices

Changes to contract scope

PPP

Strengthen prequalification department

Frameworks

D\&B

Direct sourcing

Functional / Project Management

Increased emphasis on health \& safety

Labour force changes

Risk management

Speed of project delivery

HR / Knowledge- Learning

$\begin{array}{lllll}\text { X } & \text { X } & \text { X } & \text { X } & \text { X } \\ \text { X } & \text { X } & \text { X } & & \text { X } \\ \text { X } & \text { X } & \text { X } & \text { X } & \text { X } \\ & \text { X } & \text { X } & \text { X } & \text { X } \\ & \text { X } & \text { X } & & \text { X } \\ & \text { X } & \text { X } & & \text { X } \\ & \text { X } & \text { X } & \text { X } & \\ & & \text { X } & & \text { X } \\ \text { X } & & \text { X } & \text { X } & \end{array}$

Upskilling/training

Brainstorming/lessons learnt
$\begin{array}{llll}X & X & X & X\end{array}$
X X $\quad X$
$\begin{array}{lll}X & X & X \\ & & X\end{array}$

$\begin{array}{llll}X & X & X & X\end{array}$

X $X \quad X$


Table 2 (continued)

\begin{tabular}{|c|c|c|c|c|c|c|}
\hline Response Factors & Firm Actions & $\mathbf{A}$ & B & $\mathbf{C}$ & D & $\mathbf{E}$ \\
\hline \multirow{8}{*}{$\begin{array}{l}\text { SI (government, clients, industry } \\
\text { dynamics), SR (clients) }\end{array}$} & Management conferences/roadshows & $\mathrm{X}$ & $\mathrm{X}$ & & & \\
\hline & Improved mentoring / appraisal & $\mathrm{X}$ & $\mathrm{X}$ & & & \\
\hline & Knowledge sharing/transfer & & $\mathrm{X}$ & $\mathrm{X}$ & & \\
\hline & Technology / Innovation & & & & & \\
\hline & Building information modelling (BIM) & $\mathrm{X}$ & $\mathrm{X}$ & $\mathrm{X}$ & & \\
\hline & New innovations & & $\mathrm{X}$ & & $\mathrm{X}$ & $\mathrm{X}$ \\
\hline & New document management systems & & & $\mathrm{X}$ & $\mathrm{X}$ & $\mathrm{X}$ \\
\hline & Innovation project financing & & & & $\mathrm{X}$ & \\
\hline
\end{tabular}

\section{Outcomes}

Turnaround Success $\quad x \quad X \quad$ X

$\begin{array}{llll}\text { Partial Turnaround Success } & X & X & X\end{array}$

Notes: $\mathrm{SI}=$ stakeholder influence. $\mathrm{SR}=$ stakeholder relationship.

All cases suffered organisational decline $=2$ consecutive years of turnover and profit decline.

Turnaround success $=$ profit levels in 2015 have exceeded pre-downturn levels of performance. 


\section{Case Firm A}

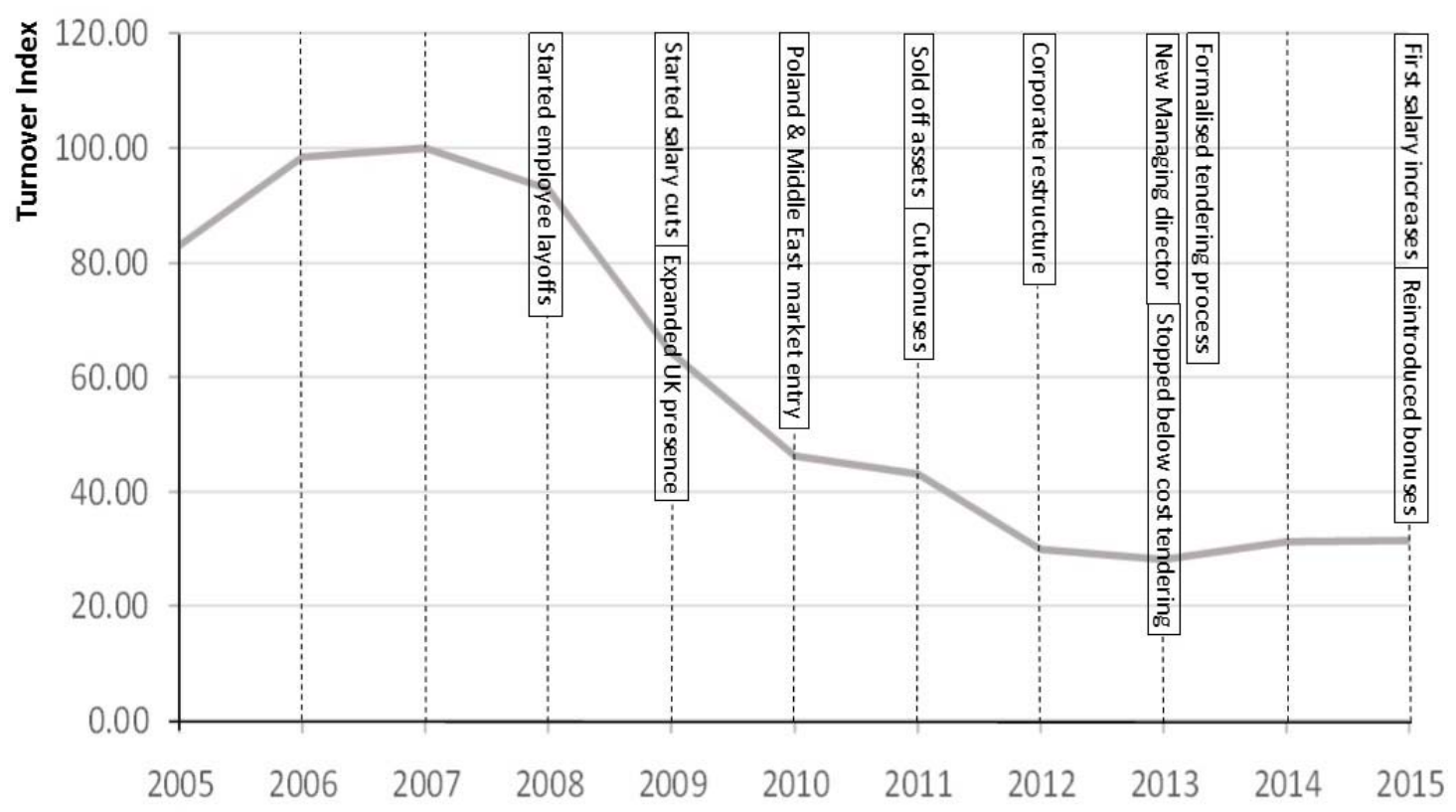

Figure 5 Mapping of turnaround strategies for Case firm A 


\section{Case Firm B}

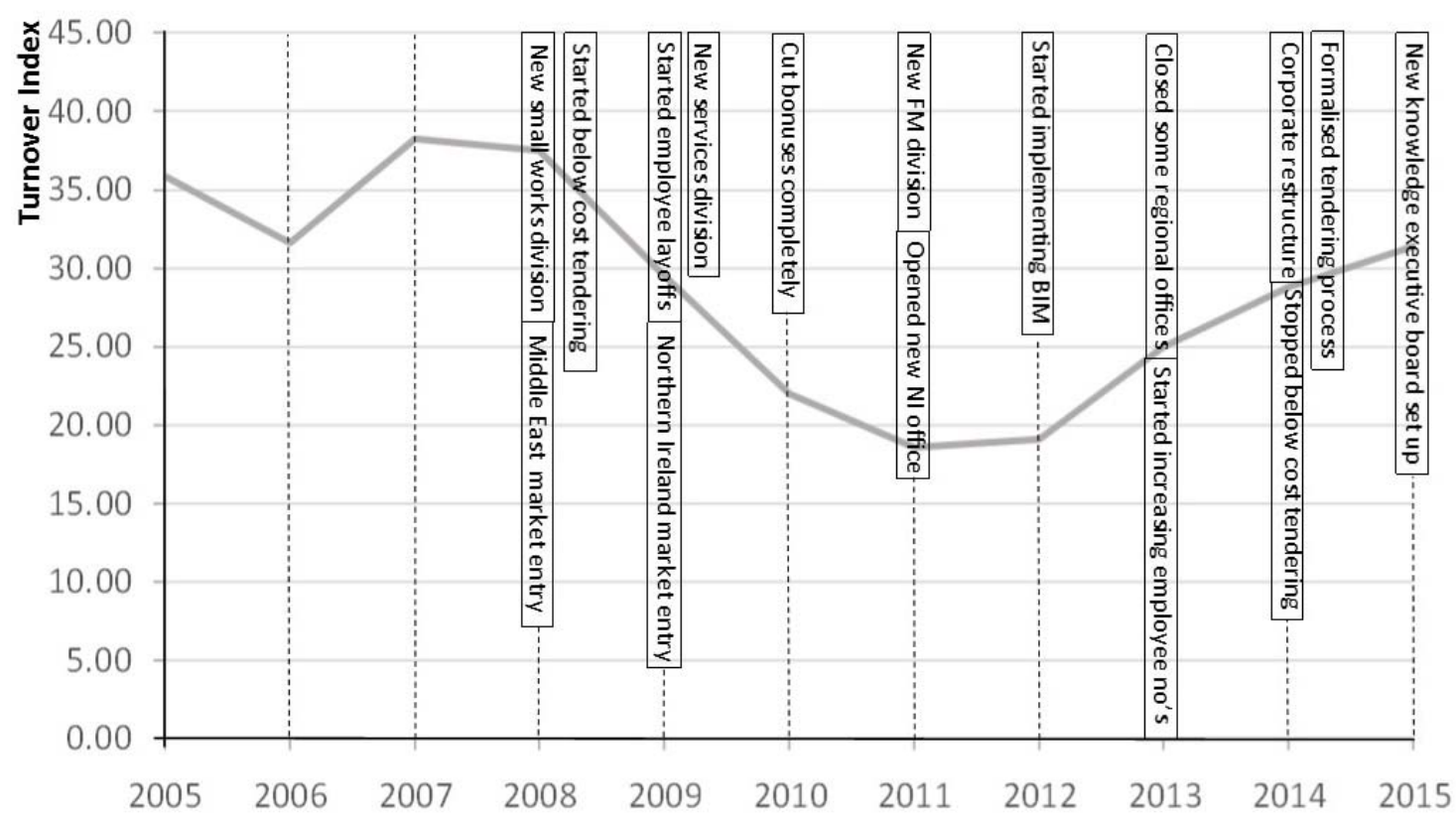

Figure 6 Mapping of turnaround strategies for Case firm B 


\section{Case Firm C}

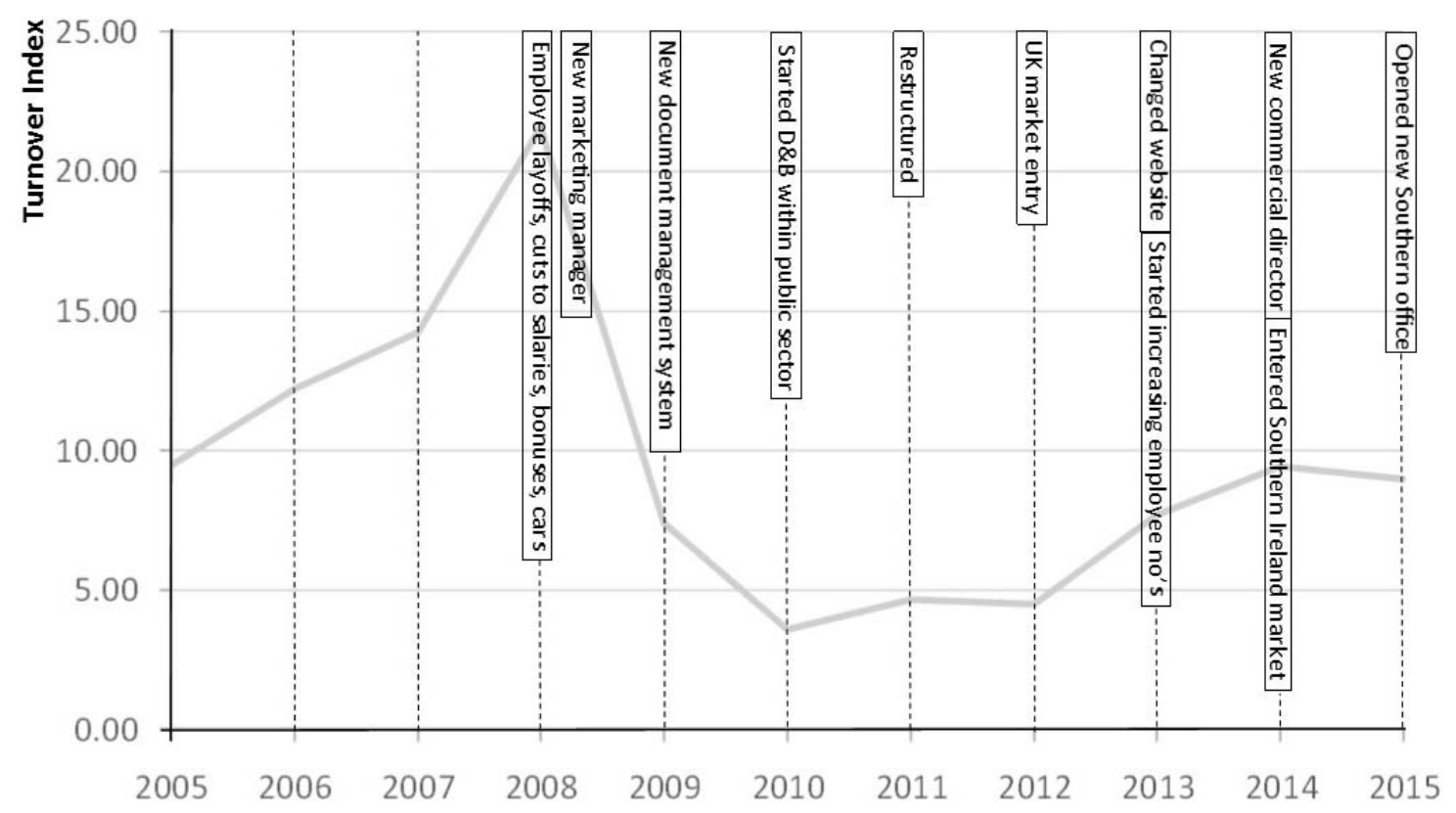

Figure 7 Mapping of turnaround strategies for Case firm $\mathrm{C}$ 


\section{Case Firm D}

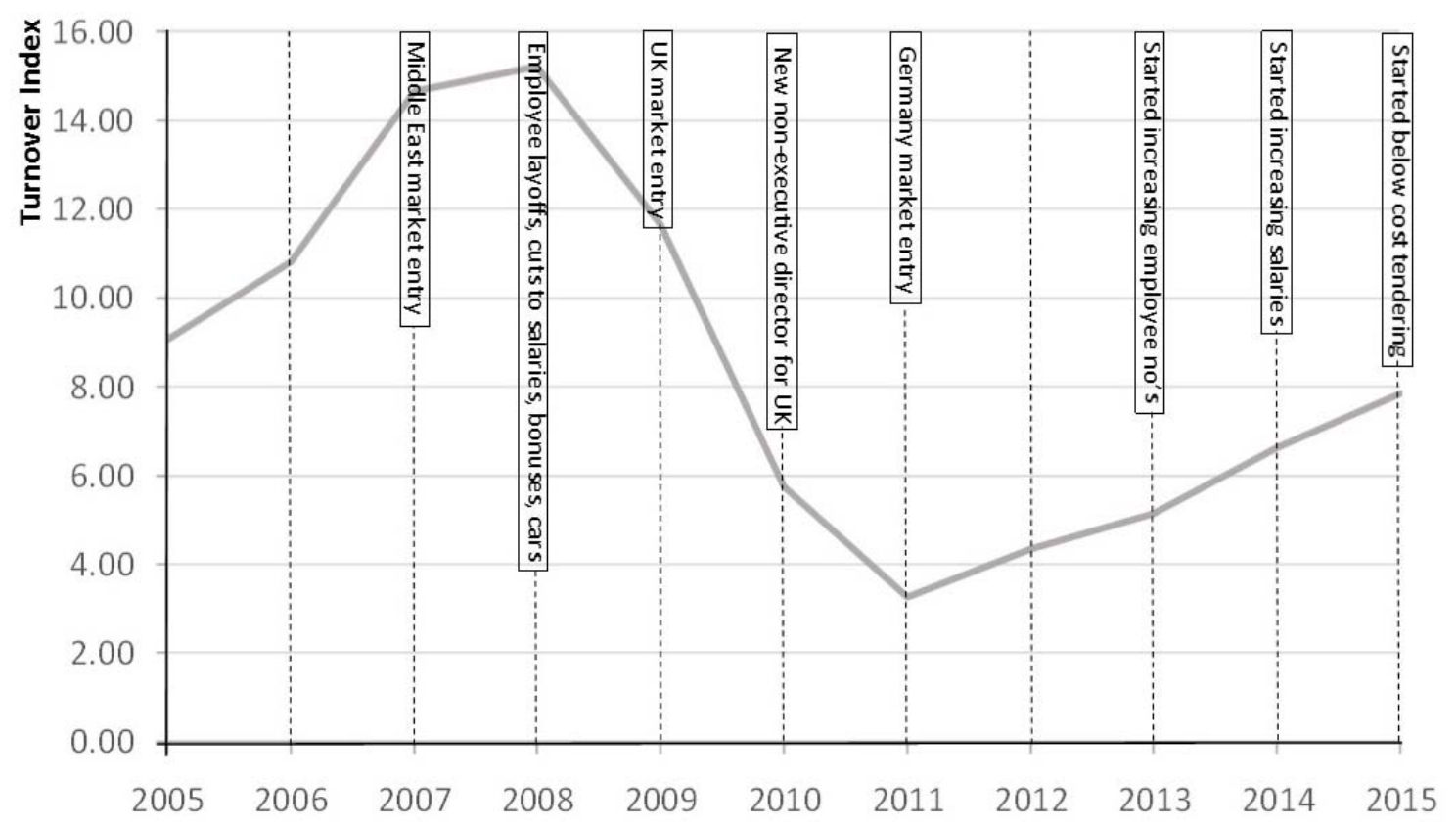

Figure 8 Mapping of turnaround strategies for Case firm D 


\section{Case Firm E}

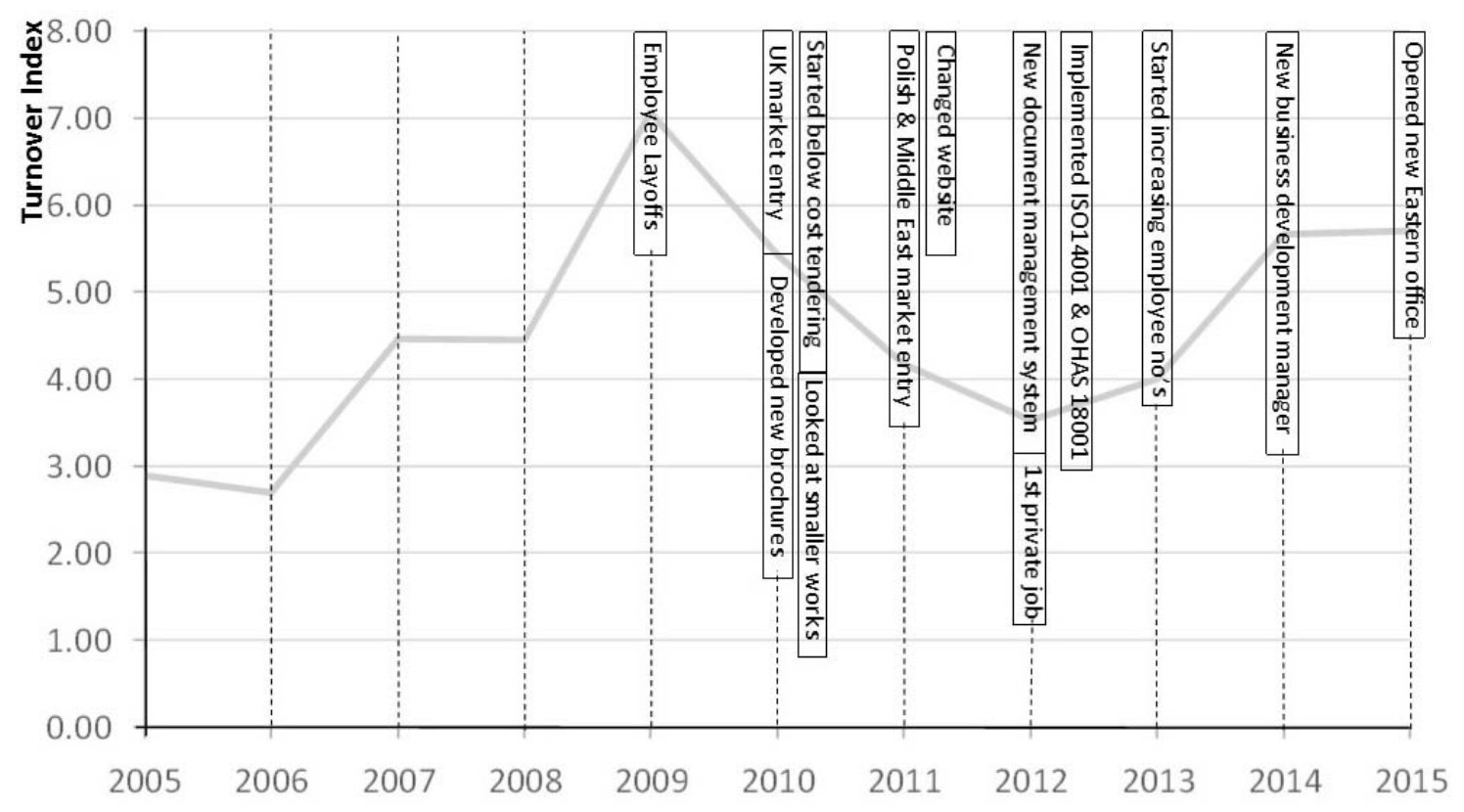

Figure 9 Mapping of turnaround strategies for Case firm E 


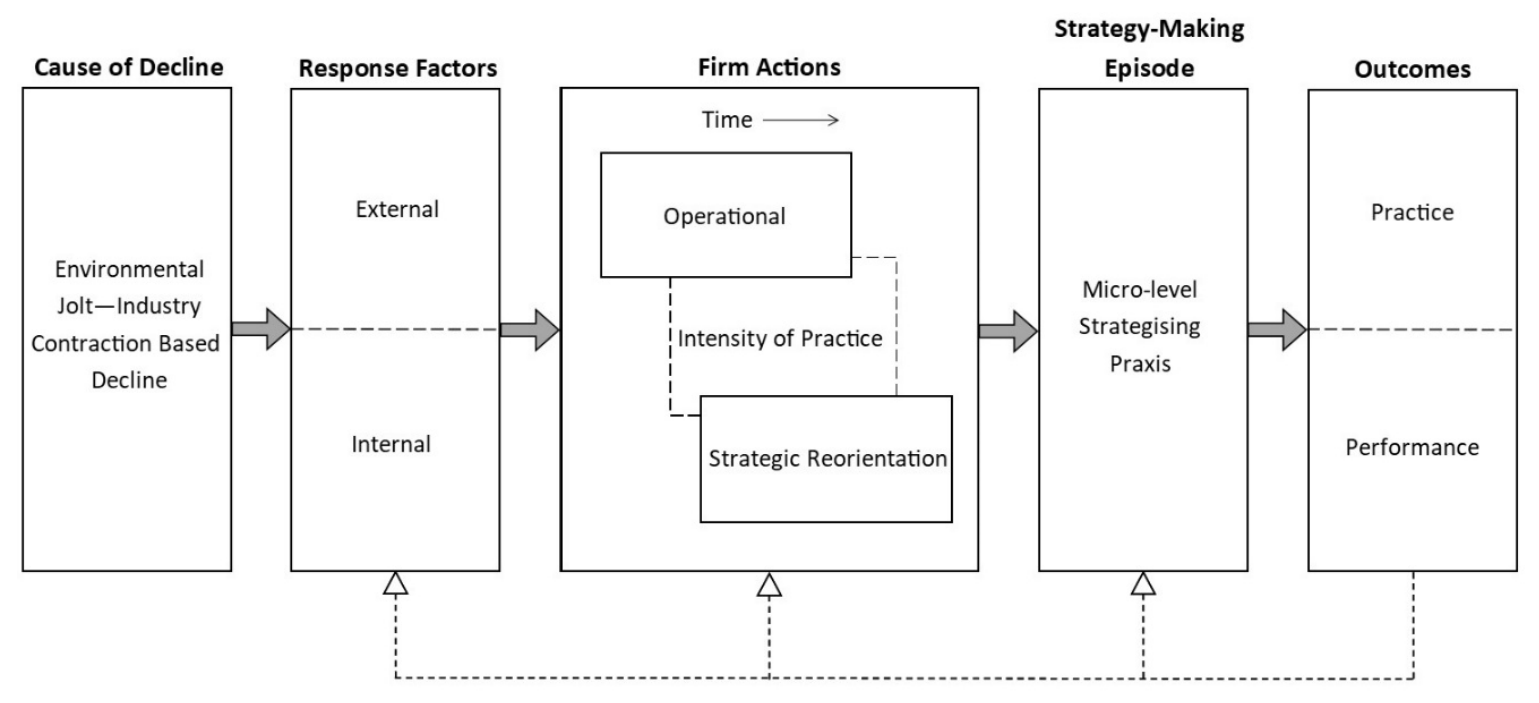

Figure 10 Turnaround Strategising Process Model 
Firm Actions

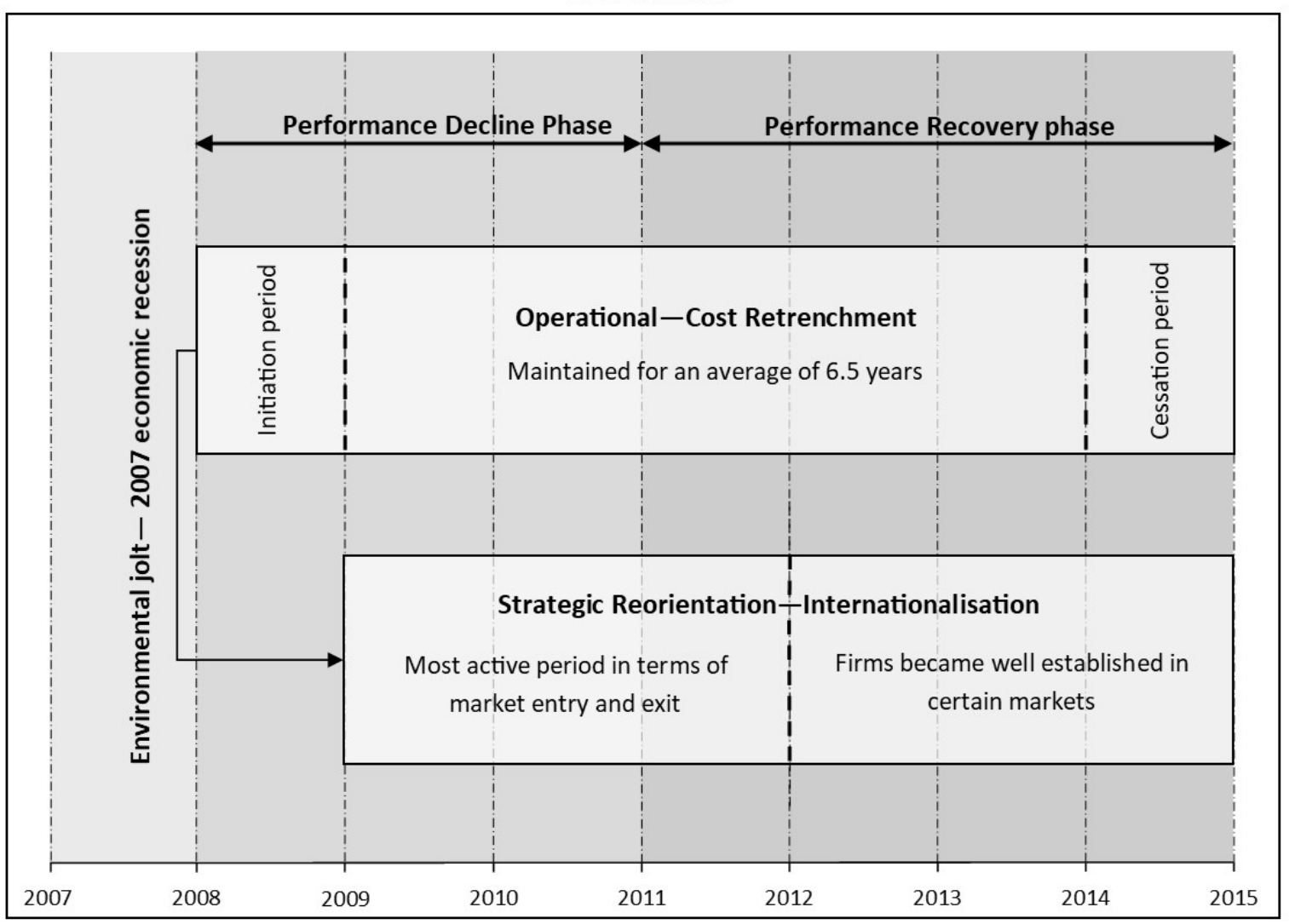

Figure 11 An Extended Process Model of Cost Retrenchment and

Internationalisation Practices 
Table 3 An overview of turnaround strategising practices

\begin{tabular}{|c|c|c|c|c|c|}
\hline Cause of decline & \multicolumn{5}{|c|}{ Industry contraction-based decline } \\
\hline $\begin{array}{l}\text { Internal response } \\
\text { factors }\end{array}$ & \multicolumn{5}{|c|}{ Level of resources, firm size, severity situation, managerial cognition } \\
\hline $\begin{array}{l}\text { External response } \\
\text { Factors }\end{array}$ & \multicolumn{3}{|c|}{$\begin{array}{l}\text { Stakeholder relationships, luck, industry } \\
\text { sector, path dependency }\end{array}$} & \multicolumn{2}{|c|}{$\begin{array}{l}\text { Industry sector, path } \\
\text { dependency }\end{array}$} \\
\hline Firm Action & \multicolumn{3}{|c|}{ Strategic reorientation } & \multicolumn{2}{|c|}{ Operational } \\
\hline Practice & \multicolumn{3}{|c|}{ Internationalisation } & \multicolumn{2}{|c|}{ Cost retrenchment } \\
\hline Intensity & Non-extensi & & Extensive & Aggressive & $\begin{array}{l}\text { Non- } \\
\text { aggressive }\end{array}$ \\
\hline Case firms & $\mathrm{B}$ and $\mathrm{E}$ & $\mathrm{C}$ and $\mathrm{D}$ & A & $\mathrm{A}, \mathrm{C}$ and $\mathrm{D}$ & $\mathrm{B}$ and $\mathrm{E}$ \\
\hline $\begin{array}{l}\text { Strategy-making } \\
\text { episode }\end{array}$ & Inductive & Abductive & Inductive & Deductive & Deductive \\
\hline Praxis & $\begin{array}{l}\text { Exploration } \\
\text { of new } \\
\text { markets } \\
\text { and sense- } \\
\text { making on } \\
\text { a small } \\
\text { scale }\end{array}$ & $\begin{array}{l}\text { Probing of } \\
\text { environment } \\
\text { and } \\
\text { exploiting } \\
\text { existing } \\
\text { relationships }\end{array}$ & $\begin{array}{l}\text { Exploration } \\
\text { of new } \\
\text { markets and } \\
\text { sense- } \\
\text { making on a } \\
\text { large scale }\end{array}$ & $\begin{array}{l}\text { Deliberate } \\
\text { practical } \\
\text { coping cuts } \\
\text { to employee } \\
\text { no's ( } 70 \%), \\
\text { salaries (10- } \\
20 \% \text { ), and } \\
\text { company } \\
\text { cars }\end{array}$ & $\begin{array}{l}\text { Deliberate } \\
\text { practical } \\
\text { coping cuts to } \\
\text { employee } \\
\text { no's }(44 \%), \\
\text { and froze } \\
\text { salaries }\end{array}$ \\
\hline Practice outcomes & Successful & Successful & $\begin{array}{l}\text { Unsuccessful } \\
\text { - withdrawal }\end{array}$ & $\begin{array}{l}\text { Stemmed } \\
\text { decline }\end{array}$ & $\begin{array}{l}\text { Stemmed } \\
\text { decline }\end{array}$ \\
\hline $\begin{array}{l}\text { Performance } \\
\text { outcomes }\end{array}$ & $\begin{array}{l}\text { Turnaround } \\
\text { success }\end{array}$ & Partial turnar & nd success & $\begin{array}{l}\text { Partial } \\
\text { turnaround } \\
\text { success }\end{array}$ & $\begin{array}{l}\text { Turnaround } \\
\text { success }\end{array}$ \\
\hline
\end{tabular}

